\title{
A long-term experimental study of the reactivity of basement rock with highly alkaline cement waters: Reactions over the first 15 months
}

\author{
C.A. Rochelle ${ }^{1}$, A.E. Milodowski ${ }^{1}$, K. Bateman ${ }^{1}$, E.B.A. Moyce ${ }^{2,3}$ and A. Kilpatrick ${ }^{1}$, \\ ${ }^{1}$ British Geological Survey, Keyworth, Nottingham, NG12 5GG, UK \\ ${ }^{2}$ The University of Leeds, Leeds, LS2 9JT, UK \\ ${ }^{3}$ Present address, Arup, Rose Wharf, Leeds, LS9 8EE, UK \\ * Corresponding author: caro@bgs.ac.uk
}

\begin{abstract}
A series of long-term laboratory experiments was started in 1995 to investigate longer-term dissolution/precipitation reactions that may occur in the alkaline disturbed zone surrounding a cementitious repository for radioactive waste. They consist of samples of UK basement rock reacting with either $\mathrm{Na}-\mathrm{K}-\mathrm{Ca}-\mathrm{OH}$ water ('young' cement porewater) or $\mathrm{Ca}-\mathrm{OH}$ water ('evolved' cement porewater) at $70^{\circ} \mathrm{C}$. This paper summarises results of reactions occurring over the first 15 months. Experiments of both fluid types showed many similar features, though primary mineral dissolution and secondary mineral precipitation were more extensive in the experiments involving $\mathrm{Na}-\mathrm{K}-\mathrm{Ca}$ (younger) cement porefluids compared to more evolved (Ca-rich) cement porefluids. Dissolution of dolomite, and to a lesser extent silicates (most probably K-feldspar, but possibly also mica) occurred relatively rapidly at $70{ }^{\circ} \mathrm{C}$. Dolomite dissolution may have been a key factor in reducing $\mathrm{pH}$ values, and may be a key mineral in controlling the extent of alkaline disturbed zones. Dissolution was followed by precipitation of brucite close to dolomite grains, at least two generations of CSH phases (which may have contained variable amounts of $\mathrm{K}, \mathrm{Al}$ and $\mathrm{Mg}$ ), overgrowths of calcite, small
\end{abstract}


crystals of hydroxyapophyllite, elongate crystals of celestite. Though hydroxyapophyllite was observed (a phase commonly associated with zeolites), there was no evidence for the formation of zeolites in the experiments. Fluid chemical changes track the mineralogical changes, with $\mathrm{CSH}$ phases being a major control on fluid chemistry. In the 'young' porewater experiments there were decreases in $\mathrm{pH}$, and $\mathrm{K}, \mathrm{Ca}$ and $\mathrm{Mg}$ concentrations, together with transitory increases in $\mathrm{SiO}_{2}$ concentrations. In the 'evolved' porewater experiments there were decreases in and $\mathrm{pH}, \mathrm{Mg}, \mathrm{Ca}$ and $\mathrm{Sr}$ concentrations, together with small increases in $\mathrm{K}$ and $\mathrm{SiO}_{2}$ concentrations. A number of experiments are still running, and will be sampled in coming years.

\section{Keywords}

Alkaline fluids, cement porewaters, alkali disturbed zone, laboratory experiments, repository evolution, radioactive waste, cement.

\section{Introduction}

The current UK concept for the disposal of low- and intermediate-level wastes (L/ILW) involves a mined geological disposal facility (GDF) several hundreds of metres below the surface (Crossland, 1998; Nirex 1989; NDA, 2010). The waste will be encapsulated in a cement grout matrix within steel or concrete containers, and placed in disposal vaults backfilled with a cement-based material. One of the main purposes of the cement is to maintain high $\mathrm{pH}$ conditions $(>\mathrm{pH} 12.5)$ that will reduce radionuclide solubility and microbial activity. Cement-equilibrated water will migrate into the surrounding host rock forming a plume of elevated $\mathrm{pH}$, alkaline water, forming a region known as the 'alkaline disturbed zone' (ADZ) (Atkinson, 1995; Savage, 1995, 2011). The pH of the cement 
porewater and of the alkaline plume will decrease over time (Atkinson, 1985; Baston et al., 2012) as differing cement components buffer the $\mathrm{pH}$ (Figure 1). The alkaline cement leachate will react with the rock causing dissolution of some minerals and precipitation of others, and this will potentially modify both the geochemical and hydrogeological properties of the host rock within the ADZ prior to any eventual radionuclide release (e.g. Baker et al., 2002; Rochelle et al., 1992; Savage, 1995; Savage et al., 1992; Savage and Rochelle, 1993). Understanding these geochemical interactions is important for predicting changes to rock porosity, fracture widths (and hence permeability and changes in groundwater flow), and minerals that may have an effect on diffusivities and sorption characteristics.

One area of uncertainty in our understanding of alkaline fluid-rock reactions is how to link data from well-constrained (but short-term) laboratory experiments with data from less well-constrained (but very much longer-term) industrial or natural analogue sites (e.g. Thomassin and Rassineux, 1992; Savage 2011). Predictive computer modelling is one way to achieve this, but the outputs from such modelling are highly dependent upon the databases used, and the codes may not adequately represent the complexities of real systems. Uncertainty can also be reduced by running laboratory experiments for timescales well in excess of just a few months to produce a more accurate and quantitative understanding of reactions within the $\mathrm{ADZ}$.

In July 1995 as part of the Nirex Safety Assessment Research Programme (NSARP), a series of long-term experiments was started to study the changes in chemistry, mineralogy and sorption properties resulting from the reaction of cement-equilibrated waters with Ordovician lower greenschist facies Borrowdale Volcanic Group (BVG) volcanisedimentary rocks, which were being considered as a potential host rock for a UK GDF. At this time, there was some uncertainty as to the nature of the secondary phases that may form over time. For example, calcium silicate hydrate $(\mathrm{CSH})$ phases are common products of alkaline fluid- 
silicate mineral reaction, but their $\mathrm{Ca}$ : $\mathrm{Si}$ ratio, degree of hydration and degree of crystallinity can change over time (Atkinson et al., 1995). Equally, there was uncertainty as to whether zeolite minerals would form. These minerals have been found to occur within a range of natural alkaline environments (e.g. Hay, 1986; Savage, 1998, 2011; Sand and Mumpton, 1978 and references therein), as a product of reaction of aggregate within Portland cement (Marfil and Maiza, 1993), and as products within alkaline fluid-rock laboratory experiments at a range of temperatures (Adler et al., 1999; Chermak, 1992, 1993; Knauss, 1987; Knauss et al., 1985). They have also been predicted to form within alkaline fluid-mineral experiments (Bateman et al., 1999) and the ADZ (Gaucher et al., 2004; Savage, 2011; Savage et al., 1992; Savage and Rochelle, 1993; Soler, 2003; Soler and Mäder, 2007; Watson et al., 2009) - especially as the $\mathrm{pH}$ of the alkaline plume decreases. However, they had not been firmly identified as products of the reaction between cement porewaters and samples of UK basement rock. If zeolites did form in the ADZ, then their high surface areas and ionexchange properties may be beneficial in the retardation of radionuclide migration (Pansini, 1996).

The experiments were originally designed to run for about 2 years, and were sampled and analysed after 4, 9 and 15 months reaction. This paper summarises the setup and results from these experiments, plus an additional set of experiments that ran for 12 months. Several ‘back-up' experiments were also started in 1995, and ran alongside those initially-sampled experiments. Following the rejection of the Nirex Rock Characterisation Facility (RCF) planning application in March 1997 and the consequent cessation of the NSARP in the late 1990s, the remaining experiments were left unopened, but they were kept running. Some of these experiments have now been examined after 15 years of reaction and are the focus of a companion paper to the one presented here (Moyce et al., 2014). The remaining experiments are still running, and will be sampled and analysed over the coming years. In the fullness of 
time, the entire suite of experiments will provide a valuable and unique set of data to aid our understanding of decadal-scale alkaline fluid-rock reactions, and be a valuable resource with which to parameterise geochemical models.

\section{Materials and methodology}

A total of 32 experiments were assembled in 1995, comprising 16 that contained alkaline fluid and granulated BVG rock, and 16 'experimental blanks' containing just alkaline fluid. Two different alkaline fluids were used (described in the following section), and consequently, the experiments could be grouped into 'sets' of four. A detailed description of the experiments is given in Rochelle et al. (1997) and a revised and updated summary of these is presented below. Subsequently, a further four sets of experiments were started (in 2013) to help address large gaps in time between some samples, and data from one of these (of 12 months duration) is also presented below.

\section{Starting solutions}

Two different synthetic cement porewaters were used, their compositions reflecting: the initial cement leachate dominated by dissolved $\mathrm{NaOH}$ and $\mathrm{KOH}$ and saturated with $\mathrm{Ca}(\mathrm{OH})_{2}$ - termed 'young' near field porewater (YNFP); and an 'evolved' near field groundwater (ENFG) representing a synthetic deep groundwater equilibrated with cement that was saturated with $\mathrm{Ca}(\mathrm{OH})_{2}$ and high in $\mathrm{Na} / \mathrm{Ca}-\mathrm{Cl}$ and $\mathrm{Na}_{2} \mathrm{SO}_{4}$ (Tables 1 and 2). The experimental fluid compositions were based on porewater compositions predicted by Bond and Tweed (1995) and Bond et al. (1995). They were prepared by the addition of pure chemical reagents to de-aired, de-ionised water under a nitrogen atmosphere to minimise uptake of atmospheric $\mathrm{CO}_{2}$. 


\section{Starting rock sample}

The disaggregated rock sample used in these experiments (sample NSF14A/30/P4) came from Sellafield borehole BH14A, west Cumbria (UK grid reference NY 0248 0569) at 858-859 $\mathrm{m}$ depth (below rotary table). It was selected to be mineralogically representative of material that would be encountered by present-day deep groundwaters in the fracturecontrolled flow system in west Cumbria (Milodowski et al., 1995; 2002). The fracture mineralisation in the Sellafield boreholes has been described in detail by Milodowski et al. $(1998 ; 2002)$. The sample contained a relatively high proportion of fracture mineralisation and associated altered BVG wallrock from two potential flowing features identified in borehole BH14A (Fortey and Shepherd, 1997):

1) Feature No. $94 / 10$-was a large fracture with vuggy cavities up to $20 \mathrm{~cm}$ long occurring in red, hematite-impregnated BVG wallrock. It was mineralised by coarse crystals of cream to pink zoned euhedral ferromanganoan dolomite and ankerite, and ferromanganoan calcite up to $10 \mathrm{~mm}$, with minor illite clay and fine earthy and specular hematite.

2) Feature No. 94/12 - comprised a vein illitic clay and hematite.

The BVG host rock for this fracture mineralisation consisted of a medium-grained, massive, volcaniclastic sandstone/tuff composed predominantly of quartz and K-feldspar, with minor albite, muscovite, chlorite and hematite.

Approximately $4 \mathrm{~kg}$ of the above sample was gently crushed to a $125-250 \mu \mathrm{m}$ grain size, with as much finer material as possible removed by delicate sieving. Quantitative XRD analysis of the major components of the sample showed it contained approximately $41 \%$ quartz, $29 \%$ dolomite, $13 \%$ mica, $12 \%$ orthoclase, $3 \%$ calcite and $2 \%$ hematite. The dolomite, calcite, hematite and most of the mica came from the fracture mineralisation. The 
high proportion of dolomite contrasts to that used in some other studies, but is typical for the mineralogy of groundwater flow paths associated with many parts of the BVG in west Cumbria (Milodowski et al., 1995; 2002).

\section{Experimental equipment}

The equipment consisted of $150 \mathrm{ml}$ (for the experiments) and $100 \mathrm{ml}$ (for the blanks), Teflon ${ }^{\circledR}$-lined, stainless steel digestion vessels. The experiments were assembled and sampled in a nitrogen $\left(\mathrm{CO}_{2}\right.$-free $)$ atmosphere inside a glove box. The wetted Teflon ${ }^{\circledR}$ parts of the equipment were first cleaned by boiling in dilute hydrochloric acid, and washed in de-ionised water followed by boiling in de-ionised water. An accurately known quantity of crushed BVG (approximately 35 g) was carefully weighed into each vessel, followed by approximately $140 \mathrm{~g}$ of either synthetic YNFP or ENFG. For the blanks, approximately $100 \mathrm{~g}$ of either porewater was added to the vessels. The lids of the vessels were securely fastened down prior to removal from the glove box. The combined volume of the alkaline solution and crushed BVG was just less than that of the vessel, so that a small $\mathrm{N}_{2}$ gas headspace/bubble resided at the top of the experiment. The experiments were placed in a thermostatically controlled oven at $70{ }^{\circ} \mathrm{C}$ (accurate to $\pm 0.5^{\circ} \mathrm{C}$ ), and were at approximately atmospheric pressure. The vessels were gently shaken/inverted by hand at regular intervals to ensure uniform reaction (approximately 3 times per week for the duration of the tests reported here). The presence of the $\mathrm{N}_{2}$ gas headspace/bubble helped ensure complete mixing of the fluid and solid.

The initial fluid:rock mass ratios in the experiments were $4: 1$. Though the volume of the water-conducting features in the original sample of BVG core were small relative to the amount of rock, groundwater movement would result in exposure of this rock to a far larger 
volume of water over time. The relatively high fluid:rock ratio in the experiments was therefore chosen to represent advection of a significant amount of cementitious water through the water-conducting features. Under in-situ conditions, the actual amount of fluid reacting with the rock will be heavily dependent on fracture properties and fluid flow rates, and we acknowledge the uncertainties in what these values may be. In terms of an experimental study, the higher fluid:rock ratio also made for more straightforward analysis of reaction products - if a significantly lower ratio had been used, then there would have been less fluid available for reaction, resulting in more subtle mineral dissolution features and much reduced precipitation of secondary phases.

\section{Fluid sampling and analysis}

Sampling of fluids and solids was carried out within a nitrogen-filled glove box and performed as soon as possible after the reaction vessels left the oven. Once in the glove box, each reactor was maintained at as close to $70{ }^{\circ} \mathrm{C}$ as possible in order to limit artefactual dissolution/precipitation reactions.

On sampling the reacted fluids, each of them was split into several subsamples, with the analysis of $\mathrm{pH}$, Eh and bicarbonate/carbonate being conducted as soon as possible. For the 4, 9 and 15 month duration experiments, $\mathrm{pH}$ was measured using an Orion ${ }^{\circledR} 520 \mathrm{~A}$ pH meter calibrated using Whatman ${ }^{\circledR}$ NBS traceable buffers at $\mathrm{pH}$ 7, 10 and 13, and Eh was measured using an Orion 96-78 platinum electrode (with internal silver/silver chloride reference electrode) connected to an Orion SA250 meter. For the 12 month duration experiments, $\mathrm{pH}$ was measured using a Thermo Scientific Orion VersaStar meter with an Orion 9103BNWP semi-micro combination $\mathrm{pH}$ electrode calibrated using Whatman ${ }^{\circledR}$ NBS traceable buffers at $\mathrm{pH}$ 7, 10 and 12.46, and Eh was measured using a Hanna Instruments HI3230 platinum 
electrode (with internal silver/silver chloride reference electrode) connected to a Thermo Scientific Orion VersaStar meter. For the data presented here, room temperature $\mathrm{pH}$ measurements and mineral saturation states were recalculated to those present in the experiments at $70{ }^{\circ} \mathrm{C}$ using PHREEQC (version 3) with the Thermochimie database (version 9a, and implemented as SIT.dat [specific ion interaction theory]). This results in slightly different $\mathrm{pH}$ values to those originally reported by Rochelle et al. (1997) using the EQ3/6 geochemical modelling software, which appears to be due to the differing species included in the databases.

A subsample of approximately $8 \mathrm{ml}$ was taken using a polythene syringe and filtered using a $0.2 \mu \mathrm{m}$ and $0.4 \mu \mathrm{m}$ Nuclepore $^{\mathrm{TM}}$ syringe filter, into a polythene tube for the subsequent analysis of major and minor anions by ion chromatography (only the $0.2 \mu \mathrm{m}$ data are presented in this paper, but they are similar to the $0.4 \mu \mathrm{m}$ data - see Rochelle et al., 1997). An accurately known, and similarly filtered, subsample of approximately $8 \mathrm{ml}$ was taken, and placed into a polystyrene tube for the subsequent analysis of major and minor cations (by ICP-OES and ICP-MS). Initially the ICP samples were acidified with $0.08 \mathrm{ml}$ of concentrated 'ARISTAR ${ }^{\circledR}$ ' nitric acid as a standard preservation procedure. However, after initial analysis of the acid-preserved samples, it was found that the results for high concentrations of Si (mainly the YNFP samples) were not consistent with each other, and that instrumental problems occurred for some samples. It was noted that if analysis was conducted within a relatively few hours of sampling and preservation, the analytical equipment performed well, and measured Si concentrations were higher. However, if the 'preserved' samples were left in cold storage for several weeks (following standard procedures at the time), the analytical equipment did not perform well, and measured Si concentrations were approximately only $10 \%$ of the expected values. It is noteworthy that the equipment operator also described these solutions as appearing to have an 'oily' viscosity. 
High concentrations of $\mathrm{Si}$ are stable in alkaline solutions, and it appears that acidification, a usual method of sample 'preservation', actually causes problems. We believed that acidification initiates Si polymerisation, or gel formation, which increases the viscosity of the sample, and impairs analysis. This process appears to be kinetically-controlled, rapid analysis does not allow the formation of larger $\mathrm{Si}$ 'structures', whereas at longer timescales these had formed to a sufficient extent to cause problems. To avoid this problem, Si analysis (by ICP-OES) was carried out on the highly alkaline 'unpreserved' samples, with standards also being prepared in alkaline medium. Although such an approach might not be suitable for many solutions, it appears very suitable for our Si-rich samples, mainly due to its high solubility in alkaline solutions. Samples from the ENFG experiments contained much less Si in solution, did not suffer problems during analysis, and hence were analysed by standard methods (sample preservation by acidification prior to analysis by ICP-OES).

Note that the data reported in Tables 1 and 2 were generated over several years. Whilst the analyses passed laboratory quality assurance criteria, there are slight differences in analytical detection limits between samples because of instrument changes and slightly different calibration procedures over time.

\section{Solids sampling and analysis}

After dismantling the experiments, the solid remaining at the bottom of each vessel was removed and subsampled: some was kept damp and sealed in an airtight container, whilst some was rapidly frozen in liquid nitrogen prior to freeze drying in an Edward's Modulyo freeze drier. The latter procedure was found to be more appropriate for subsequent mineralogical characterization.

\section{Surface Area Analysis}


The surface areas of subsamples of both unreacted and reacted disaggregated BVG material were determined by nitrogen BET adsorption/desorption method (Brunauer et al., 1938) using a Micromeritics Flowsorb II 2300 analyser. The samples were prepared by degassing at $30{ }^{\circ} \mathrm{C}$ in a vacuum oven for a minimum of 24 hours to remove water vapour and adsorbed gases prior to analysis. Surface area data were obtained by cycling the sample from room temperature to liquid nitrogen temperature (at approximately $-196{ }^{\circ} \mathrm{C}$ ) whilst immersed in a 30:70 molar ratio stream of nitrogen and helium. Due to the highly hydrated nature of potential secondary reaction products it is likely that some dehydration and consequent change in structure will have occurred. However, this effect is largely unavoidable.

\section{Scanning electron microscopy}

Unreacted and reacted BVG samples were examined by scanning electron microscopy (SEM) and environmental scanning electron microscopy (ESEM), using energy-dispersive Xray microanalysis (EDXA) to aid phase identification on the basis of qualitative microchemical information. Samples of disaggregated material were mounted on aluminium SEM stubs using double-sided carbon adhesive tabs. These were then coated with a thin layer of carbon (approximately $25 \mathrm{~nm}$ ) in order to make the surfaces electrically conductive prior to examination by secondary electron imaging. Initial SEM-EDXA analyses were carried out using a Cambridge Instruments Stereoscan S250 SEM instrument equipped with a Link Systems 860 EDXA system. Subsequently, more detailed observations were recorded using either: a LEO 435VP variable pressure SEM instrument with an Oxford Instruments ISIS 300; or a FEI QUANTA 600 ESEM instrument with a FEI QUANTA 600 tetrode gun, and equipped with an Oxford INCA 450 EDXA system. SEM observations were made using an electron beam accelerating voltage of $15-20 \mathrm{kV}$. 
Polished thin sections were also prepared from the reacted BVG material (following vacuum impregnation with epoxy resin) and examined by backscattered scanning electron imaging (BSEM). However, in most cases, observations were limited by the very small amounts of reaction product intersected in the polished sections.

\section{Analytical transmission electron microscopy}

Transmission electron microscopy (TEM) of the reaction products was undertaken using a Jeol 2010 TEM fitted with an Oxford Instruments ISIS 200 EDXA system (Nottingham Trent University). TEM with EDXA and selected area electron diffraction (SAED) was conducted using an FEI Tecnai TF20 FEGTEM with an Oxford Instruments INCA 350 EDXA system with $80 \mathrm{~mm}$ X-Max SDD detector and a Gatan Orius SC600A CCD camera (University of Leeds). Samples were prepared for TEM by ultrasonication in ethanol to liberate reaction products from the altered BVG grain surfaces. The resultant suspension was then deposited onto copper TEM grids with holey carbon films.

\section{$X$-ray diffraction analysis (XRD)}

Quantitative analysis of the bulk mineralogy and the $<2 \mu \mathrm{m}$ size fraction of the altered and unaltered samples were determined by powder X-ray Diffraction (XRD) using a PANalytical X'Pert Pro series diffractometer, with a cobalt-target tube, and X'Celerator detector operated at $45 \mathrm{kV}$ and $40 \mathrm{~mA}$. They were scanned at $4.5-85^{\circ} 2 \theta$ at $2.76^{\circ} 2 \theta /$ minute. The diffraction data were analysed using PANalytical X'Pert Highscore Plus version 2.2e software coupled to the latest version of the International Centre for Diffraction Data (ICDD) database. After identification of the mineral species present quantification was determined by Rietveld modelling (Snyder and Bish, 1989). Although different mica species may be present 
in these materials, these could not easily be differentiated and for simplicity were described simply as 'mica'.

\section{Results}

Analyses of the solutions reacted for 4, 9, 12 and 15 months are given in Tables 1 and 2. The following section gives a summary of mineralogical observation for samples from the 4, 9 and 15 month duration experiments. Tables 1 and 2 also show analyses of experimental 'blanks' (i.e. from solutions kept in Teflon ${ }^{\circledR}$-lined reactors for several months, but without any BVG present), plus analyses of de-ionised water (DIW) that served as an indicator of any sample handling/analytical issues. A selection of the data from the experiments is plotted in Figure 2.

Note that for most of the experimental 'blanks' there are small decreases in concentrations of $\mathrm{Ca}$ and $\mathrm{Si}( \pm \mathrm{Al}$ and $\mathrm{K})$. These decreases are minor compared to changes in the experiments containing crushed BVG, but they are consistent with potential slight initial oversaturation with respect to $\mathrm{CSH}$ phases (plus related calcium aluminosilicate hydrate [CASH] phases) and hence their precipitation. This may have originated from 'uncertainties' in the thermodynamic data for the $\mathrm{CSH}$ phases used in the modelling packages that predicted the starting fluid compositions. The continued decrease in concentrations over time may reflect not just continued precipitation, but also a shift towards more ordered phases having lower solubility than initially-formed disordered gels, and some modelling work is included below to investigate this.

Reactions of young cement porewater (YNFP) with BVG

Changes in fluid chemistry 
Sodium and chloride concentrations remain relatively stable throughout the 15 month duration of the experiments ( $\mathrm{Na}$ at approximately $2000 \mathrm{mg} \mathrm{l}^{-1}$, and $\mathrm{Cl}^{-}$from approximately 64 $\mathrm{mg}^{-1}$ to $400 \mathrm{mg} \mathrm{l}^{-1}$ ). The increase in chloride concentration may reflect some leaching from the rock sample - the deep groundwater from where the sample came from being appreciably saline. The relatively conservative behaviour of these elements is to be expected. Importantly however, these data indicate that significant loss of water had not occurred over the 15-month lifetime of these experiments (the steel vessels around the Teflon ${ }^{\circledR}$ liners appear to have restricted diffusional loss of water vapour). Water loss is a potential problem in any longterm experimental study as it could lead to enhanced precipitation (effectively an artefact of the experiment), increased salinity, and increased complexity in interpreting the results. This feature will be monitored in on-going, longer-term experiments.

For $\mathrm{pH}$ there was a noticeable drop from 11.7 (recalculated to $70{ }^{\circ} \mathrm{C}$ ) to 10.6 (recalculated to $70{ }^{\circ} \mathrm{C}$ ). The majority of this decrease occurred during the first 4 months of reaction, with a progressively slower rate of decrease after that. This decrease is consistent with alkaline fluid-rock reaction. This could include the dissolution of dolomite (shown in previous work by Rochelle et al. [1994a, 1998a,e] to be effective at reducing $\mathrm{pH}$, see comments in Discussion section) or the formation of CSH phases.

The likelihood of CSH phase precipitation is further enhanced by decreases in calcium concentrations from approximately $52 \mathrm{mg} \mathrm{l}^{-1}$ to $1.3 \mathrm{mg} \mathrm{l}^{-1}$ over the 15 months of the experiments. However, the small amounts of calcium initially in solution means that only limited CSH would have formed, unless calcium was also contributed from dissolution of minerals. Silica concentrations show an increase from an initial value of $9 \mathrm{mg}^{-1}$, to $2824 \mathrm{mg}$ $1^{-1}$ in the first 4 months. Subsequent to this however, the concentrations fall noticeably. Dissolution of (alumino)silicate minerals present within the BVG undoubtedly accounts for the large increase in silica, with precipitation as secondary phases (such as CSH phases) most 
likely accounting for the later, decreasing concentrations. It is likely that the falling concentration would stabilise at a steady state value if $\mathrm{CSH}$ were controlling silica concentrations, though the few data points do not allow for estimation of a value for this. The initial rate of increase of silica concentration in solution appears high. This may reflect the reactivity of the BVG towards the YNFP, although it may, in part, reflect the physical state of the starting solid. Crushing the BVG prior to reaction will have produced many small (and hence highly reactive) grains. Although care was taken to remove most of these, it is still likely that some were adhering to the larger grains and were only eventually removed by dissolution into the YNFP. In addition, it is possible that larger grains of fault gouge material disaggregated in solution, contributing to the proportion of fine-grained reactive material.

Potassium concentrations decreased from $3230 \mathrm{mg}^{-1}$ to $2230 \mathrm{mg}^{-1}$ over the 15 months of the experiments, signifying removal of potassium from solution by precipitation as a secondary phase. This interpretation is supported by the mineralogical analysis of the reacted solids (see below). Indeed, the slowing down of the rate of removal of potassium is consistent with a precipitation rate controlled by the concentration of potassium in solution and the formation of a K-rich CSH phase.. However, this does not preclude the dissolution of K-rich minerals within the BVG sample, so long as their rate of supply of potassium to solution was less than its rate of removal by precipitation.

Aluminium concentrations were $12.2 \mathrm{mg}^{-1}$ in the starting solution and initially decreased to values below the limit of detection $\left(<0.5 \mathrm{mg} \mathrm{l}^{-1}\right)$. Although it is likely that dissolution of aluminosilicate minerals (such as feldspars - see comments in the following sections) within the BVG was occurring (i.e. Al concentrations would be expected to increase over time), there appears to have been an efficient process removing aluminium from solution. Many previous studies of both natural and experimental systems (e.g. Cliff et al., 1975; Richardson et al., 1993; Linklater, 1998; Rochelle et al., 1998a,c; Richardson, 2014; 
Myers et al. 2015) have noted in excess of 5\% aluminium within CSH precipitates, so it is very possible that much of the released aluminium was being incorporated into secondary CSH identified by petrographic analysis (see below).

All the experiments had magnesium concentrations below the detection limits. This is consistent with previous studies that have shown that magnesium has very low solubility in alkaline solutions, and will rapidly precipitate as brucite (Bérubé et al., 1990; Cheng, 1986; Rochelle et al., 1994b). If, as seems likely, magnesium was released from the BVG (see comments about dolomite dissolution in the following sections), then sufficient hydroxide ions were present to ensure its immediate precipitation. The solutions also contained relatively low concentrations of strontium that were close to the limits of detection.

Sulphate concentrations are generally low, but the steady increase from below detection $\left(<1 \mathrm{mg} \mathrm{l}^{-1}\right)$ to approximately $53 \mathrm{mg}^{-1}$ suggests dissolution of a S-containing phase. Unfortunately, no S-containing phase was identified during the initial characterisation of the BVG sample. It must therefore be present in trace quantities, and so most likely has a relatively fast dissolution rate to produce the observed increase in sulphate. This is consistent with either anhydrite or pyrite dissolution, both of which have relatively fast dissolution kinetics and commonly occur as fracture-filling phases within the BVG in the Sellafield area and elsewhere in west Cumbria (Milodowski et al., 1998; 2002).

Whilst not a major component of the solutions, fluoride concentrations in the original starting solution and 4, 9 and 15 month experiments are unexpectedly high, as are those in the experimental blanks. We consider it unlikely that fluoride leached from the Teflon ${ }^{\circledR}$ reaction vessel liners as they were thoroughly boiled in dilute hydrochloric acid and water prior to use. However, the 12 month-long experiment and blank show almost no fluoride present in solution (this experiment was initiated more recently, and with a different batch of starting solution). It seems likely therefore, that much of the fluoride in the 4, 9 and 15 month 
experiments was an impurity in the starting solution. Although the original batches of chemicals used to make the starting solution were no longer available for examination, "trace" fluoride is noted in current silica standard solutions (similar to that used to add silica to the original starting solution), and this appears to be the most likely source. The potential for dissolved fluoride to stabilise the formation of F-containing phases is discussed below.

\section{Mineralogical observations}

Significant mineralogical alteration of the BVG was observed in the YNFP experiments. Dolomite grains were particularly reactive and grains were strongly etched (Figure 3a), with dissolution increasing progressively with time from 4 to 15 months. The etched dolomite surfaces were coated with a thin veneer of reaction product, which ATEM indicated to be predominantly fine (typically $<1 \mu \mathrm{m}$ ), Mg-O-rich platy crystallites, which are identified as brucite (Figure $3 \mathrm{~b}$ ). The presence of (relatively reactive) dolomite in these experiments could explain why the reduction in $\mathrm{pH}$ was so large, and the precipitation of brucite as a reaction product appears to have provided an initial sink for magnesium when the $\mathrm{pH}$ was at its highest. Minor silicate reaction is also evident with etching of quartz and $\mathrm{K}$ feldspar. In most cases the extent of primary silicate mineral surface dissolution was difficult to assess because most grain surfaces were usually obscured by extensive fine-grained primary illite clay (or sericite). SEM-EDXA analyses showed that a secondary gel-like CSH reaction product was often intimately mixed with, and difficult to resolve from, the primary illite or sericite fines on the grain surfaces that were originally present in the starting material. Some quartz and feldspar grains locally showed much more extensive development of this $\mathrm{CSH}$ reaction product, which displayed a discrete wispy and sheet-like morphology, and formed an extensive honeycomb-like coating that loosely cemented the grains together (Figure 3c). SEM-EDXA detected significant amounts of $\mathrm{K}, \mathrm{Al}$ and $\mathrm{S}$ within this reaction 
product, but it was difficult to determine whether these elements were present within discreet $\mathrm{CSH}$ or if the SEM-EDXA analyses represented an unresolved mixture of secondary CSH and fine primary illite / sericite or other phases. In contrast, higher-resolution TEM / ATEM analyses were able to more clearly resolve the $\mathrm{CSH}$ phase from primary silicate mineral fines and showed that initially (after 4 months reaction) it comprised a microfibrous phase with a low Ca:Si ratio (Figure 3d). ATEM analysis of individual CSH fibres still identified the presence of K, Al and S (Figure 3d), which suggests that these elements are actually intrinsically incorporated within the $\mathrm{CSH}$. It is possible that the $\mathrm{K}, \mathrm{Al}$ and $\mathrm{S}$ might be partially contributed from amorphous material or soluble sulphate salts admixed with the fibrous CSH that is still unresolved at the ATEM scale. However, significant aluminium substitution for silicon can occur in $\mathrm{CSH}$ phases to produce calcium aluminosilicate hydrate (CASH) gels (e.g. Richardson et al., 1993; Richardson, 2014; Myers et al., 2015). It is also feasible that at least part of the potassium might be bound within the CSH phase, particularly when Ca:Si is low (e.g. Hong and Glasser, 2002, L'Hôpital, 2014). Furthermore, some previous research has indicated that potassium uptake by $\mathrm{CSH}$ is enhanced by aluminium substitution (Hong and Glasser, 2002), though this is refuted in other studies (e.g. L'Hôpital, 2014). This reaction product developed a more flaky morphology as reaction progressed (after 9 and 15 months). No electron diffraction patterns could be obtained from the CSH reaction products, which therefore appear to be amorphous or very poorly crystalline.

In addition to the K-Al-bearing $\mathrm{CSH}$ gel, tiny euhedral crystals of a K-Ca-silicate were also observed by SEM-EDXA as a reaction product in the 4-month experiment. These crystals have a distinctive tetragonal bipyramid morphology (Figure 3e). Semi-quantitative EDXA indicated this phase has a $\mathrm{K}: \mathrm{Ca}$ ratio of approximately $1: 4$. The morphology and composition are characteristic of hydroxyapophyllite (ideal formula $\mathrm{KCa}_{4} \mathrm{Si}_{8} \mathrm{O}_{20}(\mathrm{OH}) .8 \mathrm{H}_{2} \mathrm{O}$ ) 
(cf. Deer et al., 1992). Hydroxyapophyllite was not observed in the 9 and 15 month experiments, and therefore appears to an early-formed transitory reaction product in these experiments. The initial formation of hydroxyapophyllite accompanied by K-Al bearing CSH in the first 4 months, subsequently followed by continued K-Al-bearing CSH precipitation explains the progressive decrease of potassium in the fluid whilst sodium (which is not incorporated in these phases) does not mirror potassium (Figure 2). Due to their small size $(<5 \mu \mathrm{m})$, it was not possible to analyse these tiny crystals for $\mathrm{F}$ content, and so we were unable to determine if they contained a fluorapophyllite component.

No evidence for zeolite formation was found in any of the experimental residues. Similarly, there was also no evidence for fluorite $\left(\mathrm{CaF}_{2}\right)$ in either the starting material or the reaction products. Whilst we note that minor to trace amounts of fluorite can be found in some fracture assemblages within the BVG (Milodowski et al., 1998; 2002), if it was not observed in either the starting material or the reaction products, therefore if it is presentthen it must have occurred in minute concentrations (i.e. below the levels that we could identify with the techniques used).

\section{Reactions of evolved cement porewater with BVG}

Changes in fluid chemistry

Relative to the starting solution, there was a noticeable drop in $\mathrm{pH}$ from 10.8 to 8.7 (recalculated to $70{ }^{\circ} \mathrm{C}$ ). The majority of this decrease occurred during the first 4 months of reaction, with a progressively slower rate of decrease after that. $\mathrm{pH}$ appears to be still decreasing after 15 months reaction. Such a decrease would be expected as a result of fluidrock reaction and has been observed in previous studies under the NSARP using ENFG (Rochelle et al., 1994a, 1998a, e). As with the YNFP experiments above, the magnitude of 
the $\mathrm{pH}$ decrease is probably due to relatively reactive minerals in the $\mathrm{BVG}$, especially the dolomite present in the fracture mineral assemblage (see comments in Discussion section).

As with the YNFP experiments, sodium and chloride appear relatively conservative, and have approximately constant concentrations (approximately $9000 \mathrm{mg} \mathrm{l}^{-1}$ and $16000 \mathrm{mg}^{-1}$ respectively. These relatively constant concentrations again suggest minimal loss of water during the experiments.

\#\#refs checked up to here\#\#

Calcium concentrations decreased from the initial value of $1930 \mathrm{mg} \mathrm{l}^{-1}$ to $1340 \mathrm{mg}^{-1}$ over the first 9 months of reaction, but then showed a small increase to $1530 \mathrm{mg}^{-1}$ after 15 months reaction. The initial decrease is not unexpected, as the relatively high $\mathrm{pH}$ of the solution would have favoured the formation of two potential secondary phases: calcite, and $\mathrm{CSH}$ phases. For the latter, the presence of silica from dissolution of minerals within the BVG would have caused their precipitation. This concurs with previous studies under the NSARP using ENFG reacting with BVG (Rochelle et al., 1994a, 1998a,c,e), and is consistent with the YNFP experiments above. The ENFG experiments initially contained relatively little silica in solution, and the increase in silica from $2 \mathrm{mg} \mathrm{l}^{-1}$ to $60 \mathrm{mg}^{-1}$ suggests dissolution of (alumino)silicate minerals within the BVG (e.g. quartz, muscovite and orthoclase). Though there are no clear trends within the data, the generally low concentrations in solution are consistent with CSH-type phase equilibrium (i.e. high calcium concentrations necessitate low silica concentrations).

Potassium concentrations are relatively low in the ENFG compared to the YNFP, but they do show a steady increase from $185 \mathrm{mg}^{-1}$ to $236 \mathrm{mg} \mathrm{l}^{-1}$ over the 15 months of the experiments. This increase probably reflects mineral dissolution in the BVG, the most likely candidates being K-feldspar and/or muscovite. Dissolution of these phases would have also contributed aluminium to solution, though concentrations remained low throughout the 
experiments. It is likely therefore, that an efficient process was removing aluminium from solution, potentially via incorporation into secondary phases, such as CSH or CKSH gel-like phases noted earlier.

The decrease in strontium from $166 \mathrm{mg}^{-1}$ to $66 \mathrm{mg}^{-1}$ indicates precipitation of small amounts of a secondary phase. The trend in the data, with a falling rate of decrease, suggests an approach to a steady state value in the region of $50 \mathrm{mg} \mathrm{l}^{-1}$. This decrease is consistent with the observation of secondary celestite in the reacted mineral assemblage (see below). The driving mechanism for celestite precipitation may well have been initial oversaturation with this phase, however, its formation after ettringite breakdown can not be ruled out (see below). Celestite precipitation would have been favoured by the relatively high concentrations of dissolved sulphate in the ENFG, which remained at approximately $1060 \mathrm{mg}^{-1}$ throughout the experiments.

As per the YNFP experiments, magnesium concentrations remained below detection limits, and these are consistent with previous studies showing that appreciable amounts of magnesium are not stable in alkaline solutions, and it will rapidly precipitate as brucite (Bérubé et al., 1990; Cheng, 1986; Rochelle et al., 1994b).

Fluoride concentrations were much lower in the ENFG experiments $\left(<1 \mathrm{mg} \mathrm{l}^{-1}\right)$ compared to the YNFP experiments, including the 'blank' runs. This appears to strengthen the case for the fluoride having come from an impurity in the silica solution added to the starting solution of the YNFP experiments (silica was not added to the starting ENFG solution).

\section{Mineralogical observations}

Reaction of the BVG with the ENFG also resulted in corrosion and dissolution of dolomite (Figure 4a). Although dolomite reaction is dominated by dissolution in these 
experiments, the reacted dolomite after 9 months showed evidence for the secondary formation of very fine (up to $2 \mu \mathrm{m}$ ) overgrowths of secondary calcite on the etched grain. These overgrowths appeared to be syntaxially (crystallographically) orientated to the underlying dolomite substrate, and gave the dolomite a 'sugary' appearance under the SEM (Figure 4b).

Quartz, K-feldspar, albite and muscovite were also all observed to have reacted with ENFG after 9 and 15 months, but little alteration was evident in the 4-month experiment. The extent of secondary precipitation was more limited than in the YNFP experiments, probably because of the lower $\mathrm{pH}$ (i.e. lower reactivity) of the starting fluid. The principal reaction product is an amorphous $\mathrm{Ca}( \pm \mathrm{K}, \mathrm{Al})$ silicate hydrate gel, which formed a very thin film over the primary silicate minerals (Figure 4c). This phase was more abundant in the 4 month experiment compared to the 9 and 15 month experiments, which may indicate dissolution of this phase as the fluid $\mathrm{pH}$ decreased during the course of the experiments, as reaction progressed. Although apophyllite was tentatively identified as a trace phase by Rochelle et al. (1997) in the 4 month duration experiments, subsequent re-analysis of the very limited amounts of remaining sample showed no evidence for it. No zeolites or fluorite were observed.

Well-formed, acicular crystals of celestite $\left(\mathrm{SrSO}_{4}\right)$ were also found in the residues from the 4, 9 and 15 month-long experiments (Figure 4d) (this phase was originally miss-reported by Rochelle et al. (1997) as strontianite). The crystals range from 1 to $200 \mu \mathrm{m}$ in size and typically display very smooth crystal faces. The precipitation of this phase explains the progressive decrease in stronitum in the fluid from 4 to 15 months (Figure 2).

\section{Discussion}


This experimental study has aged samples of Borrowdale Volcanic Group material from a current, transmissive, groundwater flow zone, with young and evolved cement porewater at $70{ }^{\circ} \mathrm{C}$ for 4,9 and 15 months. Analyses revealed changes associated with dissolution of primary minerals and development of secondary phases.

\section{Reaction of BVG with young cement porefluid (YNFP)}

Initial fluid-rock reaction of these more alkaline fluids (i.e. dissolution of the starting BVG) is clearly demonstrated through a progressive reduction in $\mathrm{pH}$ (from 11.7 to 10.6 when recalculated to $70{ }^{\circ} \mathrm{C}$ ). The majority of this decrease occurred during the first 4 months of reaction, and was probably aided by the preferential reaction of the finer grains of the BVG. The trend in $\mathrm{pH}$ suggests approach towards a steady-state value of about 10.2, though with prolonged reaction this would no-doubt eventually decrease further. This $\mathrm{pH}$ value is consistent with (possibly temporary) buffering by a secondary phase, probably the (K- and Al-rich) CSH phase. Such a decrease in $\mathrm{pH}$ has been observed in previous studies under the NSARP (Savage et al., 1992; Rochelle et al., 1994a, 1998a,b,e). Indeed, one of these studies (Rochelle et al., 1998b) noted that dolomite was particularly influential in this respect due to its relatively fast reaction kinetics and tendency to react to form brucite (Mg-hydroxide), effectively removing hydroxyl ions from solution (the sample of BVG used in that study contained $25 \%$ dolomite, cf. $29 \%$ used in this study). Other studies have also noted the formation of brucite (and potentially calcite) as a result of $\mathrm{NaOH}$-rich fluids reacting with dolomite (Cheng, 1986; Choquette, 1991; Hadley, 1961; Mohnot and Bae, 1985):

$$
\mathrm{CaMg}\left(\mathrm{CO}_{3}\right)_{2}+2 \mathrm{OH}^{-} \Rightarrow \mathrm{Ca}^{2+}+\mathrm{Mg}(\mathrm{OH})_{2}+2 \mathrm{CO}_{3}^{2-}
$$

Dolomite

brucite 
Reaction of dolomite was observed, with pitting on dolomite grains associated with platy crystals of brucite (Figure 3a,b). Other grains (silicate minerals) showed only minor etching, though were covered with secondary $\mathrm{C}(\mathrm{KA}) \mathrm{SH}$ gel, and grains of gouge material appeared to have disaggregated to produce a large amount of fine particles. The latter are thought to have provided a large surface area for reaction to occur. Carbonate mineral dissolution is faster than silicate mineral dissolution by several orders of magnitude (Brady and Walther, 1989; Chou et al., 1989; Rochelle et al., 1994b, 1998d), and the higher degree of pitting on dolomite is consistent with this.

Continued reduction in $\mathrm{pH}$ through fluid-rock reaction will eventually result in the destabilisation of brucite, though this did not appear to have occurred during the 15 month duration of the experiments describe here. It is anticipated that this will eventually result in the re-release of magnesium to solution. It is noteworthy that Rochelle et al. (1998b) suggest the possible formation of a smectitic clay as a product of the reaction of YNFP with dolomite-rich BVG. Adler et al. (1999) also identify the dissolution of dolomite/ankerite as a source of magnesium to solution, and that this helped drive clay mineral formation in their experiments. Longer-duration experiments would reveal if clays were a stable reaction product as the $\mathrm{pH}$ decreased (cf. Moyce et al., 2014).

The dissolution of dolomite ( \pm silicate minerals) will also have contributed calcium to solution. This will have added significant amounts of calcium to the limited amount in the starting fluid, and combined with silica released through the dissolution of silicate minerals will have helped form the extensive CSH gel precipitate.

That measured calcium concentrations decreased over time suggests that the rate of $\mathrm{CSH}$ precipitation was more than sufficient to keep pace with input of calcium from the dissolving BVG. The solutions also contained large concentrations of dissolved silica which 
appears to have resulted from relatively fast dissolution of finer grains of BGS relatively early in the experiments. Previous work (Savage et al., 1992) has already noted the inverse solubility relationship between calcium and silica for conditions of CSH phase saturation. The gel was not pure $\mathrm{CSH}$, but contained abundant potassium and aluminium, and this is also consistent with CSH precipitates in previous experimental studies (Rochelle et al., 1998a, c; Savage et al., 1992). The potassium and aluminium were probably mainly sourced from Kfeldspar and/or muscovite dissolution, which would have also contributed silica to solution. The CKASH phase probably controlled the solubility of calcium, potassium, aluminium and silica throughout most of the duration of the experiments.

The initial gel appeared to have a more 'fibrous' morphology, whilst the later gel appeared to have a more 'flaky' morphology and contained more aluminium. It is unclear if the change in morphology is linked to the change in composition, or the relative age of the CSH (i.e. it may slowly transform to more ordered structures over time). The gel may have been showing some signs of undergoing re-dissolution in the 15-month experiment. This may be a sign of the $\mathrm{pH}$ reduction through continued fluid-rock reaction causing the initially formed CSH to become unstable, possibly itself breaking down to form other phases (such as $\mathrm{CSH}$ of a different composition or clays) as the $\mathrm{pH}$ of the system evolved. Longer-duration experiments would reveal if this were the case (see Moyce et al., 2014). The surface area of the reaction products increased relative to the starting material, reaching a maximum increase of $39 \%$ after 9 months reaction, though this later fell to a $30 \%$ increase after 15 months reaction. This trend in surface area is consistent with the precipitation, and subsequent partial dissolution, of the CKASH gel.

The dissolution of dolomite will also have increased the partial pressure of $\mathrm{CO}_{2}\left(\mathrm{Pco}_{2}\right)$ in the reactor, and there is evidence for higher concentrations of bicarbonate/carbonate in the longer duration experiments. Interestingly, Adler et al. (1999) conducted experiments at 30 
${ }^{\circ} \mathrm{C}$ reacting Opalinus Clay with a Na-K-Ca-OH alkaline fluid at $\mathrm{pH} 13.2$ (equivalent to a young porefluid) for between 4 and 18 months. They report that zeolite formation was supressed by addition of $\mathrm{CO}_{2} /$ bicarbonate/carbonate to solution, and similar observations were made by Thompson (1971). Adler et al. (1999) also report that zeolite formation was favoured in rock pore spaces, where fluid fluxes and fluid-rock ratios were very low. We sought evidence for zeolite formation, though none was found. This may possibly be explained by our experiments having a relative abundance of water, and having significant dolomite dissolution that increased inorganic carbon concentrations. The aluminium and silica needed for zeolite formation appear to have mainly gone into the CSH (CASH, CKASH) phases mentioned previously. The potential exists therefore, for zeolites to still form within the $\mathrm{BVG}$, though they might require a carbonate-poor rock-dominated environment, and hence not be expected in water-conducting, carbonate-lined fractures.

Though zeolites were not found, tiny crystals of hydroxyapophyllite (ideal formula $\mathrm{KCa}_{4} \mathrm{Si}_{8} \mathrm{O}_{20}(\mathrm{OH}) .8 \mathrm{H}_{2} \mathrm{O}$ ) were found amongst the $\mathrm{CSH}$ gel, having a euhedral tetragonal bipyramidal morphology (Figure 3e). Hydroxyapophyllite is often associated geologically with zeolites, such as in the alkaline alteration of basalts (e.g. Deer et al., 1992). Only small quantities of this phase were found, and it is thought that it may have only been formed early in the experiments when calcium and potassium concentrations were relatively high and when silica concentrations were increasing. Detailed analysis of these small crystals proved difficult, and we were unable to determine if they contained a fluorapophyllite component. However, had this been significant in this phase, then we would have expected fluoride concentrations in solution to increase once it re-dissolved - this was not observed. Indeed, the experiments at 4, 9 and 15 months show, if anything, a decreasing trend in fluoride concentrations (12 month data not included as they show negligible fluoride). 
The continuous, linear increase of sulphate throughout the experiments appears to indicate that certain trace components of the BVG were undergoing constant dissolution throughout the experiments. XRD did not identify a S-rich phase, so it would appear to be present in only very minor quantities. The most likely candidates for the source of the sulphate would be anhydrite dissolution or pyrite oxidation, both of which are known to occur within some fracture mineral assemblages in the BVG.

Mineral saturation state modelling using PHREEQC and the Thermochimie database showed that fluorite was slightly undersaturated in all the experiments (Table 3). It seems unlikely therefore that the accidental addition of fluoride to the YNFG starting solution caused precipitation of this phase. The saturation states of a number of $\mathrm{CSH}$ phases were also calculated (Table 3), but the very low concentrations of aluminium in solution greatly hindered meaningful calculation of Al-phase saturation indexes (including CASH phases). Overall, the $\mathrm{CSH}$ phases that were saturated in the starting solution were relatively Ca-rich, with a high Ca:Si ratio. However, over time the phases that were saturated changed to those with lower $\mathrm{Ca}$ :Si ratios. This pattern is consistent with increasing dissolution of minerals in the BVG supplying progressively more silica as reaction progresses,

\section{Reaction of BVG with evolved cement porefluid (ENFG)}

There were many similarities between these experiments and the ones using the YNFP. Again, initial fluid-rock reaction whilst fluids were more alkaline (i.e. dissolution of the starting BVG) was clearly demonstrated through a rapid reduction in $\mathrm{pH}$ (from 10.8 to a nearly steady value of 8.7 when recalculated to $70{ }^{\circ} \mathrm{C}$ ). Virtually all of this decrease occurred during the first 4 months of reaction, and was probably aided by the preferential reaction of the finer grains of the BVG. This $\mathrm{pH}$ value is again consistent with buffering by a secondary phase, probably the (K- and Al-rich) $\mathrm{CSH}$ phase. It is noteworthy that the relative $\mathrm{pH}$ 
decrease between starting solution and experiments is much larger for the ENFG compared to the YNFP. This probably reflects the amount of hydroxyl ions in each solution (in essence, the solution 'buffering capacity'). The ENFG is based upon only limited amounts of $\mathrm{Ca}(\mathrm{OH})_{2}$, which could be consumed by reaction relatively quickly, and hence $\mathrm{pH}$ would decrease relatively rapidly. Conversely, the YNFP contains more hydroxyl ions due to the addition of significant $\mathrm{NaOH}$ and $\mathrm{KOH}$ as well as $\mathrm{Ca}(\mathrm{OH})_{2}$, and so (for a given rate of consumption of hydroxyl ions) would show a slower $\mathrm{pH}$ decrease.

The reaction of dolomite with fluids rich in $\mathrm{Ca}(\mathrm{OH})_{2}$ bears many similarities to the reaction of dolomitic aggregate with high-alkali portland cement. The latter commonly produces a solids volume increase, expansion, and cracking of concrete (e.g. Galí et al., 2001). Other workers (e.g. Bérubé et al., 1990; Poole and Sotiropoulos, 1980) note that dolomite is reactive in the presence of lime and $\mathrm{Ca}(\mathrm{OH})_{2}$-rich solutions to produce brucite and calcite.

$$
\begin{array}{ccc}
\mathrm{CaMg}\left(\mathrm{CO}_{3}\right)_{2} & \mathrm{Ca}(\mathrm{OH})_{2} \Rightarrow \\
\text { dolomite } & \mathrm{Mg}(\mathrm{OH})_{2}+2 \mathrm{CaCO}_{3} \\
\text { brucite } & \text { calcite }
\end{array}
$$

Dissolution of the starting BVG was mainly confined to dolomite grains (in the form of pitting), however after 15 months of reaction K-feldspar also showed some signs of corrosion. It is thought that much of the $\mathrm{pH}$ reduction was due to the dissolution of dolomite, with most overall reaction occurring early in the experiments when the $\mathrm{pH}$ was at its highest. Dissolution of K-feldspar (or possibly muscovite) is thought to have added much of the potassium and silica to solution. The continued linear increase in potassium from $185 \mathrm{mg}^{-1}$ to $236 \mathrm{mg} \mathrm{l}^{-1}$ over 15 months appears to indicate that this continued throughout the experiments. It is noteworthy that such a trend is the opposite of the YNFP case, where (the 
initially much higher) potassium concentrations fall throughout the experiments. This can be explained by the continued, more extensive incorporation of potassium into CKASH gels in the YNFP experiments (higher $\mathrm{pH}$ ), but only limited amounts of K-rich CSH phases in the ENFG experiments (at least over the timescales sampled).

Compared to the YNFP experiments, there were relatively minor amounts of secondary precipitates present in these experiments. Secondary $\mathrm{CSH}( \pm \mathrm{K})$ products were more abundant in the 4-month experiment compared to the 15-month experiment, and it appears that some precipitates which developed initially dissolved subsequently as the fluid $\mathrm{pH}$ decreased. This dissolution appeared to add little extra calcium or silica to solution, possibly because of the generally minor abundance of early precipitates, or because they were subsequently reprecipitated as other phases. There was evidence for minor calcite formation on dolomite surfaces after 9 months of reaction. The surface areas of the reaction products initially decreased by $30 \%$, but after 15 months had risen to almost their starting value. This may be explained by infilling or blocking of porosity within the grains by the relatively small quantities of secondary products. Subsequent removal of these by re-dissolution would have exposed much of the original porosity. Re-dissolution might help explain the increase in calcium concentration at 15 months (though conclusions are tentative as only a single datum is involved). Whilst dissolution of CSH could have increased calcium concentrations, it might also be expected to increase silica in solution, but there is no evidence for this. An explanation for this could be an evolution of $\mathrm{CSH}$ phase composition (CSH phases can have a wide range of $\mathrm{Ca}: \mathrm{Si}$ ratios), so there is a possibility that a more Si-rich $\mathrm{CSH}$ phase precipitated later in the experiments at the expense of a more Ca-rich one. The potential for this was explored through geochemical modelling of CSH saturation states using PHREEQC and the GEMS databse, as per the YNFP cases (Table 4). A similar pattern emerged, with saturation of relatively $\mathrm{Ca}$-rich $\mathrm{CSH}$ phases predicted in the starting solution. However, these 
changed over time, and became dominated by more Si-rich CSH phases through progressive reaction with the minerals in the BVG.

There is only tentative evidence for hydroxyapophyllite formation after 4 months of reaction, but not at longer timescales. If it did form, this again suggests rapid formation early in the experiment, followed by its re-dissolution as the $\mathrm{pH}$ of the solution evolved towards lower values.

Celestite was observed as per the YNFP experiments and was the only secondary sulphate phase identified. However, previous studies (Rochelle et al., 1994b, 1998a,c) using more evolved cement porewaters noted initial precipitation of the sulphate mineral ettringite $\left(\mathrm{Ca}_{6} \mathrm{Al}_{2}\left(\mathrm{SO}_{4}\right)_{3}(\mathrm{OH})_{12} \cdot 26 \mathrm{H}_{2} \mathrm{O}\right)$, which can be followed by its dissolution as it becomes destabilised as a result of $\mathrm{pH}$ decrease (Rochelle et al., 1994b). Unfortunately, there was no mineralogical evidence for this in the present sets of experiments (such as impressions of ettringite needles in mats of CSH as reported by Rochelle et al., 1994b). A reason for this may be that previous studies reacting powdered BVG with ENFG (Rochelle et al., 1994b, 1998a,c,e) had short durations, not exceeding 4 months long. It is entirely conceivable that ettringite precipitated initially in the current set of long-term experiments, but subsequently dissolved (though this remains conjecture). If ettringite did form and then dissolve, initially precipitated sulphate would have been returned to solution, possibly with some proportion of it precipitating as celestite. Consequently, the observed sulphate concentrations are not inconsistent with previous experiments under the NSARP. Running repeat experiments over much shorter timescales would be one way to check this possibility.

\section{Discussion and implications for the near repository environment}

In the performance assessment for a cement-based repository for radioactive waste, it will be necessary to consider the alkaline, chemically-disturbed zone. In order to understand 
the temporal and spatial evolution of this zone, it will also be necessary to consider how fluid-conductive features such as fractures evolve when they are filled with a high $\mathrm{pH}$ fluid that is out of equilibrium with the host rock. Previous experimental and modelling studies (Rochelle et al., 1994a; 1998a,b,c,e; Savage et al., 1992; Savage and Rochelle 1993) undertaken as part of the NSARP have highlighted the importance of CSH phases and ettringite in reducing porosity, in coating fracture surfaces and increasing mineral surface areas available for sorption.

In the set of experiments presented here, the BVG sample used was taken from a potential flowing feature, and should thus provide information on reactions most likely to occur when hyperalkaline fluids migrate along currently open fractures. Use of a sample of fracture fill is more realistic than using samples of bulk rock, as the latter may not actually contact alkaline fluids to any significant extent. The sample used in this study contained much fine-grained gouge material and dolomite, both of which appeared to contribute to the relatively fast reaction of the rock, and relatively rapid reduction in $\mathrm{pH}$ of the alkaline solutions. This reaction appeared to be most noticeable when the $\mathrm{pH}$ was highest. One feature of such fast reaction was the rapid formation of secondary phases, which included: significant amounts of a secondary $\mathrm{C}(\mathrm{K}, \mathrm{A}) \mathrm{SH}$ gel, some hydroxyapophyllite, and some brucite in the YNFP experiments; and more limited amounts of $\mathrm{C}(\mathrm{K}) \mathrm{SH}$ gel, some celestite, minor calcite and potentially trace hydroxyapophyllite in the ENFG experiments.

The presence of significant dolomite in the starting solid is particularly noteworthy. Whilst this phase might be relatively more uniformly distributed within sedimentary host rocks (e.g. Adler et al., 1999), it could be restricted only to fracture fills within fractured basement rocks such as the BVG (Milodowski et al., 1998; 2002). In the latter therefore, though it may make up a tiny fraction of the total rock mass it could be a highly significant proportion of fracture assemblages. As alkaline fluids migrating through fractured rock will 
be focussed along these fractures, the reactivity of dolomite will have an impact far greater than would be suggested by its overall abundance in the rock mass. The observations from this study have wider application than to just the BVG in the UK. A dolomite-bearing host rock mineralogy is also relevant to a number of potential repository and underground research laboratory (URL) sites being considered elsewhere, including: the Opalinus Clay (Jurassic) in Switzerland (Wenk et al., 2008); the Callovo-Oxfordian (Jurassic) shales in the Meuse/Haute-Marne site near Bure in France (Wenk et al., 2008); the Boom Clay (Tertiary) at the Mol site in Belgium (Honty and De Craen, 2009); Tertiary mudrocks at the Horonobe URL site, Hokkaido, Japan (Kunimaru et al., 2010); and fracture mineralisation in the Archaen basement rocks of the Olkiluoto site in Finland (Kuva et al., 2012).

Dolomite may also play two other important roles as well as its ability to reduce solution $\mathrm{pH}$. Firstly, its dissolution will increase $\mathrm{Pco}_{2}$ locally, and this may supress the formation of secondary zeolites (Adler et al., 1999; Thompson, 1971). This may therefore limit the benefit that would be gained through ion-exchange and retardation of migrating radionuclides into zeolites. Secondly, its dissolution followed by calcite precipitation may help seal the wall of fractures, reducing diffusion and uptake of radionuclides into the rockmatrix. This has been shown via diffusion-reaction calculations undertaken by Steefel and Lichtner (1994, 1998). Although their calculations were undertaken for fractures in a sedimentary rock, similar processes may occur for less permeable basement rocks. They predicted that carbonate production by dolomite dissolution, coupled with interdiffusion of calcium from the infiltrating high-pH solution, has the potential to significantly reduce matrix porosity of rock immediately adjacent to the fracture through calcite precipitation. 
Insufficient information exists from these experiments to quantify how the solids volume changed during the experiments. However, given the apparent abundance of the (K/Al-rich) CSH gel in some of the experiments, then it (qualitatively) appears to have a potentially important role in modifying fracture porosity. This phase also appears to have appreciable surface area, which would be of benefit when considering the retardation of radionuclides by sorption. Conversely however, a coating of precipitate may also isolate the rock matrix to some extent, and so it may have an impact on the accessibility of the rock matrix to radionuclide diffusion. Further investigations are needed to determine the relative contributions of each of these processes, and hence ascertain whether radionuclide migration would be enhanced or retarded.

Although phases such as hydroxyapophyllite, and possibly the very K-rich CSH gel, have not previously been observed within experiments conducted as part of the NSARP, they are not entirely unexpected. K-rich CSH can occur within cements (Hong and Glasser, 2002, L'Hôpital, 2014), and hydroxyapophyllite is commonly associated with zeolites as an alteration product of basalts by moderately alkaline fluids (Deer et al., 1992). In terms of contributing to improvements in predictive geochemical modelling of alkaline fluid-fracture assemblages, it is important that thermodynamic data for these phases are included within model databases. No zeolites were observed in the experiments. There are several possible reasons for their absence, and it is not yet possible to identify which of these is the controlling factor. One or more of the following could have been key: rapid removal of aluminium and silica from solution by the formation of a range of $\mathrm{CSH}$ (CASH, CKASH) phases, slow zeolite precipitation kinetics at the temperatures used, relatively high $\mathrm{Pco}_{2}$ in the experiments, and a relatively high fluid/rock ratio. The data obtained from this study suggest therefore, that zeolites would not be expected in water-conducting, carbonate-lined fractures, 
and this should be considered when undertaking predictive geochemical modelling of alkaline fluid-fracture assemblages.

\section{Conclusions}

Re-investigation of a series of old experiments is providing an unique opportunity to study longer-term fluid-rock reaction processes within alkaline plumes, and this study shows that it is possible to follow alkali fluid-rock reactions within experimental systems for months to years. Some of the geochemical and mineralogical changes are broadly in line with previous experimental, modelling and analogue studies, though others are new. Dissolution of dolomite, and to a lesser extent silicates (most probably K-feldspar, but possibly also mica) occurred relatively rapidly at $70{ }^{\circ} \mathrm{C}$ and were apparent within just a few months. Dolomite dissolution may have been a key factor in reducing $\mathrm{pH}$ values, and may be a key mineral in controlling the extent of alkaline disturbed zones. Dissolution was followed by precipitation of brucite close to dolomite grains, at least two generations of CSH phases (which may have contained variable amounts of $\mathrm{K}, \mathrm{Al}$ and $\mathrm{Mg}$ ), overgrowths of calcite, small crystals of hydroxyapophyllite, elongate crystals of celestite. Though hydroxyapophyllite was observed (a phase commonly associated with zeolites), there was no evidence for the formation of zeolites in the experiments. Precipitation was more extensive in the experiments involving Na-K-Ca (younger) cement porefluids compared to more evolved (Ca-rich) cement porefluids. With continued fluid-rock reaction however, some of these initially-formed phases had begun to re-dissolve as continued fluid-rock reaction reduced the $\mathrm{pH}$ of the coexisting fluid.

This investigation highlights the importance of running longer-term experiments to study processes that cannot be examined during (the more common) short-term laboratory studies. The relatively simple experimental equipment aids long-duration tests, and a number 
of identical experiments continue to run. These will be sampled at increasing timescales, and eventually will provide quantitative data on alkaline fluid-rock reaction over several decades.

\section{Acknowledgements}

The Nirex Safety Assessment Research Programme (NSARP) is acknowledged for funding the initiation of the experiments and initial analyses. The reaction products were reexamined as part of Biogeochemical Gradients and RADionuclide transport (BIGRAD) project funded by the Natural Environment Research Council (NERC) (grant reference NE/H005927/1). E. Moyce was funded by the Engineering and Physical Sciences Research Council (EPSRC) through the Nuclear Fission Research, Science and Technology (Nuclear FiRST) Doctoral Training Centre (DTC) (grant number: EP/G037140/1). The authors acknowledge numerous other BGS staff who have helped keep the experiments running since 1995 and provided fluid chemistry, XRD and SEM/TEM analytical data, including: P. Blackwell, M. Cave, P. Coombs, C. Gowing, K. Green, S.J. Kemp, A.M. Lacinska, J.M. Pearce, G. Purser, S. Reeder, C. Richardson and J. Trick. This paper is published with the permission of the Executive Director of the British Geological Survey (NERC). 


\section{References}

Adler, M., Mäder, U.K. and Waber, H.N. (1999) High-pH alteration of argillaceous rocks; an experimental study. Schweizerische Mineralogische und Petrographische Mitteilungen, 79, 445-454.

Atkinson, A. (1985) The time dependence of $\mathrm{pH}$ within a repository for radioactive waste disposal. United Kingdom Atomic Energy Authority Report, AERE-R11777, United Kingdom Atomic Energy Research Establishment, Harwell, UK.

Atkinson, A., Harris, A.W. and Hearne, J.A. (1995) Hydrothermal alteration and ageing of synthetic calcium silicate hydrate gels. Nirex UK Limited, Safety Studies Report, NSS/R374, 24pp.

Baker, A.J., Bateman, K., Hyslop, E.K., Ilett, D.J., Linklater, C.M., Milodowski, A.E., Noy, D.J., Rochelle, C.A. and Tweed, C.J. (2002) Research on the alkaline disturbed zone resulting from cement-water-rock reactions around a cementitious repository. UK Nirex Ltd. Report, N/054.

Baston, G.M.N., Clacher, A.P., Heath, T.G., Hunter, F.M.I., Smith, V. and Swanton, S.W. (2012) Calcium silicate hydrate $(\mathrm{C}-\mathrm{S}-\mathrm{H})$ gel dissolution and $\mathrm{pH}$ buffering in a cementitious near field. Mineralogical Magazine, 76(8), 3045-3053.

Bateman, K., Coombs, P., Noy, D.J., Pearce, J.M., Wetton, P., Haworth, A. and Linklater, C. (1999) Experimental simulation of the alkaline disturbed zone around a cementitious radioactive waste repository: numerical modelling and column experiments. In, R. Metcalfe and C.A. Rochelle (eds), Chemical Containment of waste in the Geosphere. Geological Society of London Special Publication, 157, 183-194.

Bérubé, M-A., Choquette, M. and Locat, J. (1990) Effects of lime on common soil and rock forming minerals. Applied Clay Science, 5, 145-163.

Bond, K.A. and Tweed, C.J. (1995) Groundwater compositions for the Borrowdale Volcanic Group, Boreholes 2, 4 and RCF3, Sellafield, evaluated using thermodynamic modelling. UK Nirex Ltd, Report, NSS/R397, 34p.

Bond, K.A., Moreton, A.D. and Tweed, C.J. (1995) Water compositions of relevance to a deep cementitious-based repository at Sellafield: Evaluation using thermodynamic modelling. UK Nirex Ltd, Report, NSS/R310, 25p.

Brady, P.V. and Walther, J.V. (1989) Controls on silicate dissolution rates in neutral and basic $\mathrm{pH}$ solutions at $25^{\circ} \mathrm{C}$. Geochimica et Cosmochimica Acta, 53, 2823-2830.

Brunauer, S., Emmett, P.H. and Teller, E. (1938) Adsorption of gases in multimolecular layers, Journal of the American Chemical Society, 60, 309-319.

Cheng, K.H. (1986) Chemical consumption during alkaline flooding: A comparative evaluation. Proceedings of the SPE/DOE $5^{\text {th }}$ Symposium on Enhanced Oil Recovery. SPE/DOE paper 14944, SPE, 2, 259-272.

Chermak, J.A. (1992) Low temperature experimental investigation of the effect of high $\mathrm{pH}$ $\mathrm{NaOH}$ solutions on the Opalinus Shale, Switzerland. Clays and Clay Minerals, 40, 650658.

Chermak, J.A. (1993) Low temperature experimental investigation of the effect of high $\mathrm{pH}$ $\mathrm{KOH}$ solutions on the Opalinus Shale, Switzerland. Clays and Clay Minerals, 41, 365372.

Choquette, M., Bérubé, M.-A. and Locat, J. (1991) Behaviour of common rock-forming minerals in a strongly basic $\mathrm{NaOH}$ solution. Canadian Mineralogist, 29,163-173.

Chou, L., Garrels, R.M. and Wollast, R. (1989) Comparative study of the kinetics and mechanisms of dissolution of carbonate minerals. Chemical Geology, 78, 269-282.

Cliff, G., Gard, J.A., Lorimer, G.W. and Taylor, H.F.W. (1975) Tacharanite. Mineralogical Magazine, 40, 113-126. 
Crossland, I.G. (1998) The role of engineered barriers in a UK repository for intermediate level radioactive waste. Interdisciplinary Science Reviews, 23, 269-280.

Deer, W.A., Howie, R.A. and Zussman, J. (1992) An Introduction to the Rock Forming Minerals (2nd edition). Longman, England, $696 \mathrm{pp}$.

Fortey, N.J. and Shepherd, T.J. (1997) The petrology of flow zones and potential flowing features in Sellafield Borehole 14A. UK Nirex Ltd Report, 755, 149pp.

Galí, S., Ayora, C., Alfonso, P., Tauler, E. and Labrador, M. (2001) Kinetics of dolomiteportlandite reaction. Application to Portland cement concrete. Cement and Concrete Research, 31, 933-939.

Gaucher, E.C., Blanc, P., Matray, J-M. and Michau, N. (2004) Modeling diffusion of an alkaline plume in a clay barrier. Applied Geochemistry, 19, 1505-1515.

Hay, R.L. (1986) Geologic occurrence of zeolites and some associated minerals. Pure and Applied Chemistry, 58, 1339-1342.

Hadley, D.W. (1961) Alkali reactivity of carbonate rocks - expansion and dedolomitization. Highway Research Board Proceedings, 40, 462-474.

Hong, S.,-Y. and Glasser, F.P. (2002) Alkali sorption by C-S-H and C-A-S-H gels. Part II. Role of alumina. Cement and Concrete Research, 32, 1101-1111.

Honty, M. and De Craen, M. (2009) Mineralogy of the Boom Clay in the Essen-1 borehole. External Report, Belgium Nuclear Research Centre, SCK•CEN-ER-87 09/Mho/P-35, 39pp. SCK •CEN, Mol, Belgium.

Knauss, K.G. (1987) Zeolitization of glassy Topopah Spring Tuff under hydrothermal conditions. In: Scientific Basis for Nuclear Waste Management X, (eds J.K. Bates and W.B. Seefeldt), Materials Research Society Symposium Proceedings, 84, 737-745.

Knauss, K.G., Delany, J.M., Beitinger, W.J., and Peifer, D.W. (1985) Hydrothermal interaction of Topopah Spring Tuff with J-13 water as a function of temperature. In: Scientific Basis for Nuclear waste Management VIII (eds C.M. Jantzen, J.A. Stone and R.C. Ewing). Materials Research Society Symposium Proceedings, 44, 539-546.

Kunimaru, T., Ota, K., Alexander, W.R. and Yamamoto, H. (2010) Groundwater/porewater hydrochemistry ay Horonobe URL:Data Freeze I - Preliminary data quality evaluation for boreholes HDB-9, 10 and 11. JAEA Research, 2010-035, 109pp. Japan Atomic Energy Agency, Tokai-mura, Ibaraki-ken, Japan.

Kuva, J., Myllys, M., Timonen, J., Kelokaski, M., Ikonen, J., Siitari-Kauppi, M., Lindberg, A. and Aaltonen, I. (2012) Microstructure, porosity and mineralogy around fractures in Olkiluoto bedrock. Posiva Report, 2012-02, 114pp. Posiva Oy, Olkiluoto, Urajoki, Finland.

L'Hôpital, E. (2014) Aluminium and Alkali Uptake in Calcium Silicate Hydrates (C-S-H). Thesis, Doctor of Sciences, Thèsis No 6389 (2014), École Polytechnique Fédérale de Lausanne, Switzerland.

Linklater, C.M (editor) (1998) A natural analogue study of cement-buffered, hyperalkaline groundwaters and their interaction with a repository host rock. United Kingdom Nirex Limited Science Report, S/98/003. United Kingdom Nirex Limited (Nirex), Harwell, Oxfordshire.

Marfil, S.A. and Maiza, P.J. (1993) Zeolite crystallization in Portland cement concrete. Cement and Concrete Research, 23, 1283-1288.

Milodowski, A.E., Gillespie, M.R., Shaw, R.P. and Bailey, D.E. (1995) Flow-zone characterisation: mineralogical and fracture orientation characteristics in the PRZ and Fleming Hall Fault Zone area boreholes, Sellafield. UK Nirex Ltd, Report, SA/95/001.

Milodowski, A.E., Gillespie, M.R., Naden, J., Fortey, N.J., Shepherd, T.J., Pearce, J.M. and Metcalfe, R. (1998) The petrology and paragenesis of fracture mineralization in the 
Sellafield area, west Cumbria. Proceedings of the Yorkshire Geological Society, 52, 215-241.

Milodowski, A.E., Fortey, N.J., Gillespie, M.R., Pearce, J.M. and Hyslop, E.K. (2002) Synthesis report on the mineralogical characteristics of fractures from the Nirex boreholes in the Sellafield area. British Geological Survey, Technical Report, WG/98/8, $1011 \mathrm{pp}$.

Mohnot, S.M. and Bae, J.H. (1985) A study of mineral-alkali reactions: Part 2. Society of Petroleum Engineers, paper 13576, 18pp.

Moyce, B.A., Rochelle, C., Morris, K., Chen, X., Thornton, S., Small, J.S. Milodowski, A.E., and Shaw, S. (2014). Rock alteration in alkaline cement waters over 15 years and its relevance to the geological disposal of nuclear waste. Applied Geochemistry, 50, 91105.

Myers, R.J., L'Hôpital, E., Provis, J.L. and Lothenbach, B. (2015). Effect of temperature and aluminium on calcium (alumina)silicate hydrate chemistry under equilibrium conditions. Cement and Concrete Research, 68, 83-93.

NDA (2010) Geological disposal steps towards implementation. NDA Report NDA/RWMD/013, NDA, Harwell.

Nirex (1989) Deep repository project. Preliminary environmental and radiological assessment and preliminary safety report. UK Nirex Ltd Report, $\mathbf{7 1 .}$

Pansini, M. (1996) Natural zeolites as cation exchangers for environmental protection. Mineralium Deposita, 31, 563-575.

Poole, A.B. and Sotiropoulos, P. (1980) Reactions between dolomitic aggregate and alkali pore fluids in concrete. Quarterly Journal of Engineering Geology, 13, 281-287.

Richardson, I.G., Brough, A.R., Brydson, R., Groves, G.W. and Dobson, C.M. (1993) Location of aluminium in substituted calcium silicate hydrate (C-S-H) gels as determined by ${ }^{29} \mathrm{Si}$ and ${ }^{27} \mathrm{Al} \mathrm{NMR}$ and EELS. Journal of the American Ceramic Society, 76, 2285-2288.

Richardson, I.G., (2014) Model structures for C-(A)-S-H(I). Acta Crystallographica Section B: Structural Science, Crystal Engineering and Materials, 70, 903-923.

Rochelle, C.A., Bateman, K., Milodowski, A.E., Noy, D., Pearce, J., Savage, D. and Hughes, C.R. (1992) Reactions of cement pore fluids with rock: Implications for the migration of radionuclides. In (Y.K Kharaka and A.S. Maest eds) Proceedings of the $7^{\text {th }}$ International Symposium on water-Rock Interaction - WRI-7, 13-18 July 1992, Park City, Utah, 423-426.

Rochelle, C.A., Bateman, K., Coombs, P., Pearce, J.M. and Wetton, P. (1998a) The evaluation of chemical mass transfer in the disturbed zone of a deep geological disposal facility for radioactive wastes. VIII. Further reactions involving powdered Borrowdale Volcanic Group lithologies with synthetic evolved near-field groundwater. UK Nirex Ltd. Science Report, NSS/R393, 33p.

Rochelle, C.A., Bateman, K., Coombs, P., Pearce, J.M. and Wetton, P. (1994a) The evaluation of chemical mass transfer in the disturbed zone of a deep geological disposal facility for radioactive wastes. IX. Further reactions involving discs of Borrowdale Volcanic Group lithologies with synthetic evolved near-field groundwater. British Geological Survey, Technical Report, WE/94/45C, 30p.

Rochelle, C.A., Bateman, K., Gardner, S.J., Pearce, J.M. and Wetton, P. (1994b) The evaluation of chemical mass transfer in the disturbed zone of a deep geological disposal facility for radioactive wastes. VII. The kinetics of dissolution of calcite and dolomite at elevated $\mathrm{pH}$. British Geological Survey Technical Report, WE/94/44C, $47 \mathrm{p}$. 
Rochelle, C., Bateman, K., Hughes, C., Pearce. J, and Savage. D. (1998b) The evaluation of chemical mass transfer in the disturbed zone of a deep geological disposal facility for radioactive wastes. III. Reaction of Borrowdale Volcanic group lithologies with Na-KCa hydroxide fluids. UK Nirex Ltd Science Report, NSS/R327, 42p.

Rochelle, C.A., Bateman, K., MacGregor, R., Pearce, J.M., Prior, S.V. Savage, D. and Wetton, P. (1998c) The evaluation of chemical mass transfer in the disturbed zone of a deep geological disposal facility for radioactive wastes. VI. The hydrothermal aging of disks of bulk rock and near-fracture Borrowdale Volcanic Group lithologies with a synthetic alkaline near-field groundwater. UK Nirex Ltd. Science Report, NSS/R390, $34 \mathrm{p}$.

Rochelle, C.A., Bateman, K., MacGregor, R., Pearce, J.M., Savage, D. and Wetton, P. (1998d) The evaluation of chemical mass transfer in the disturbed zone of a deep geological disposal facility for radioactive wastes. IV. The kinetics of dissolution of chlorite and carbonates at elevated $p H$. UK Nirex Ltd. Science Report, NSS/R368, $81 \mathrm{p}$.

Rochelle, C.A., Bateman, K., MacGregor, R., Pearce, J.M., Savage, D. and Wetton, P. (1998e) The evaluation of chemical mass transfer in the disturbed zone of a deep geological disposal facility for radioactive wastes. $V$. The hydrothermal aging of powdered hematised and near-fracture Borrowdale Volcanic Group lithologies with a synthetic alkaline near-field groundwater. UK Nirex Ltd. Science Report, NSS/R382, $23 \mathrm{p}$.

Rochelle, C.A., Pearce, J.M., Bateman, K., Coombs, P. and Wetton, P.D. (1997) The evaluation of chemical mass transfer in the disturbed zone of a deep geological disposal facility for radioactive wastes. X. Interaction between synthetic cement porefluids and BVG: Observations from experiments of 4, 9 and 15 months duration. British Geological Survey, Technical Report, WE/97/16C, 79p.

Sand, L.B. and Mumpton, F.A. (eds) (1978) Natural Zeolites: Occurrence, Properties, Use. Pergamon, Oxford, ISBN 0-08-021922-5, 546 pp.

Savage, D. (ed) (1995) The scientific and regulatory basis for the geological disposal of radioactive waste. John Wiley and Sons, Chichester, England, ISBN 0-471-96090-X, $437 \mathrm{p}$.

Savage, D. (1998) Zeolite occurrence, stability and behaviour. In J.A.T Smellie (ed.) MAQARIN natural analogue study: Phase III, SKB Technical Report, TR-98-04, 281316.

Savage, D. (2011) A review of analogues of alkaline alteration with regard to long-term barrier performance. Mineralogical Magazine, 75, 2401-2418.

Savage, D., Bateman, K., Hill, P., Hughes, C.J., Milodowski, A.E., Pearce, J.M., Rae E. and Rochelle, C.A. (1992) Rate and mechanism of the reaction of silicates with cement pore fluids, Applied Clay Science, 7, 33-45.

Savage, D. and Rochelle, C.A. (1993) Modelling reactions between cement pore fluids and rock: implications for porosity change. Journal of Contaminant Hydrology, 13, 365378.

Savage, D., Walker, C., Arthur, R., Rochelle, C., Oda, C., Takase, H. (2007). Alteration of bentonite by hyperalkaline fluids: A review of the role of secondary minerals. Physics and Chemistry of the Earth, 32, 287-297.

Snyder, R.L. and Bish, D.L. (1989) Chapter 5. Quantitative analysis. In: Bish, D.L. and Post, J.E. (eds), Modern Powder Diffraction, Reviews in Mineralogy, 20, Mineralogical Society of America, USA, 101-144.

Soler, J.M. (2003). Reactive transport modelling of the interaction between a high-pH plume and a fractured marl: the case of Wellenberg. Applied Geochemistry, 18, 1555-1571. 
Soler, J.M. and Mäder, U.K. (2007) Mineralogical alteration and associated permeability changes induced by a high-pH plume: Modelling of a granite core infiltration experiment. Applied Geochemistry, 22, 17-29.

Steefel, C.I. and Lichtner, P.C. (1994) Diffusion and reaction in rock matrix bordering a hyperalkaline fluid-filled fracture. Geochimica et Cosmochimica Acta, 58, 3595-3612.

Steefel, C.I. and Lichtner, P.C. (1998) Multicomponent reactive transport in discrete fractures II: Infiltration of hyperalkaline groundwater at Maqarin, Jordan: a natural analogue site. Journal of Hydrology, 209, 200-224.

Thomassin, J.H. and Rassineux, F. (1992) Ancient Analogues of cement-based materials: stability of calcium silicate hydrates. Applied Geochemistry, Supplementary Issue No. 1, 137-142.

Thompson, A.B. (1971) $\mathrm{pCO}_{2}$ in low grade metamorphism; zeolite, carbonate, clay mineral prehnite relations in the system $\mathrm{CaO}-\mathrm{Al}_{2} \mathrm{O}_{3}-\mathrm{SiO}_{2}-\mathrm{CO}_{2}-\mathrm{H}_{2} \mathrm{O}$. Contributions to Mineralogy and Petrology, 33, 145-161.

Watson, C., Hane, K., Savage, D., Benbow, S., Cuevas, J. and Fernandez, R. (2009) Reaction and diffusion of cementitious water in bentonite: results of 'blind' modelling. Applied Clay Science, 45, 54-69.

Wenk, H.-R., Voltolini, M., Mazurek, M., Van Loon, L.R. and Vinsot, A. (2008) Preferred orientations and anisotropy in shales: Callovo-Oxfordian Shale (France) and Opalinus Clay (Switzerland). Clays and Clay Minerals, 56, 285-306. 
FIG. 1. Schematic illustration of the evolution of cement pore fluid $\mathrm{pH}$ as a function of time (redrawn after Atkinson (1985) for a repository diameter of $20 \mathrm{~m}$ containing $185 \mathrm{~kg} \mathrm{~m}^{-3}$ of cement, a temperature of $25^{\circ} \mathrm{C}$, and with a groundwater flux density of $10 \mathrm{e}^{-10} \mathrm{~m} \mathrm{~s}^{-1}$ ).

FIG. 2. Plots of selected fluid chemical data for the starting solution, and at 4, 9, 12 and 15 months. Squares represent the young porewater experiments, circles represent the evolved porewater experiments.

FIG. 3. (a) SEM (secondary electron) image of corroded dolomite grain (9 months YNFP experiment). (b) TEM image of well-developed brucite crystals adjacent to dolomite (9 months YNFP experiment). (c) SEM image showing extensive CSH reaction product coating altered BVG fragments (9 months YNFP experiment). (d) TEM image and EDXA spectra of fibrous CSH reaction product and primary platy illite (9 months YNFP experiment). (e) and (f) SEM images of euhedral tetragonal bipyramid apophyllite crystals formed as reaction products ( 4 months YNFP experiment).

FIG. 4. (a) SEM (secondary electron) image of corroded dolomite grain displaying deep etching along cleavage ( 9 months ENFG experiment). (b) SEM image showing sugary coating of very fine secondary calcite overgrowths on reacted dolomite surface ( 9 months ENFG experiment). (c) $\mathrm{CSH}$ reaction product coating altered BVG fragments (9 months ENFG experiment). (d) Euhedral acicular crystal of celestite growing on the surface of a BVG fragment encrusted with fine particulate material cemented by $\mathrm{CSH}$ ( 9 months ENFG experiment). 
TABLE 1. Summary of fluid chemical information for YNFP experiments. Data are presented for the composition of the starting fluid, together with final compositions of YNFP+BVG experiments and YNFP 'blanks' at 4, 9, 12 and 15 months.

TABLE 2. Summary of fluid chemical information for ENFG experiments. Data are presented for the composition of the starting fluid, together with final compositions of ENFG+BVG experiments and ENFG 'blanks' at 4, 9, 12 and 15 months.

TABLE 3. Selected mineral saturation state data for YNFP experiments. Data are presented for the starting fluid, together with final compositions of YNFP+BVG experiments and YNFP 'blanks' at 4, 9, 12 and 15 months.

TABLE 4. Selected mineral saturation state data for ENFG experiments. Data are presented for the starting fluid, together with final compositions of ENFG+BVG experiments and ENFG 'blanks' at 4, 9, 12 and 15 months. 


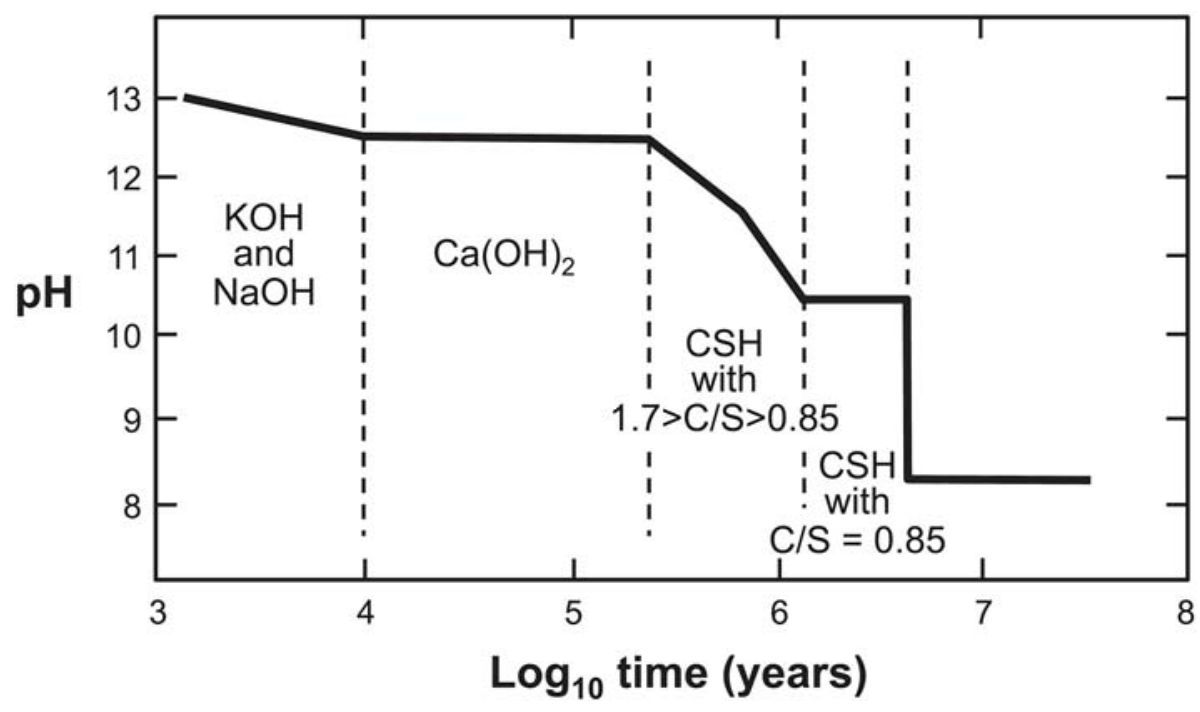



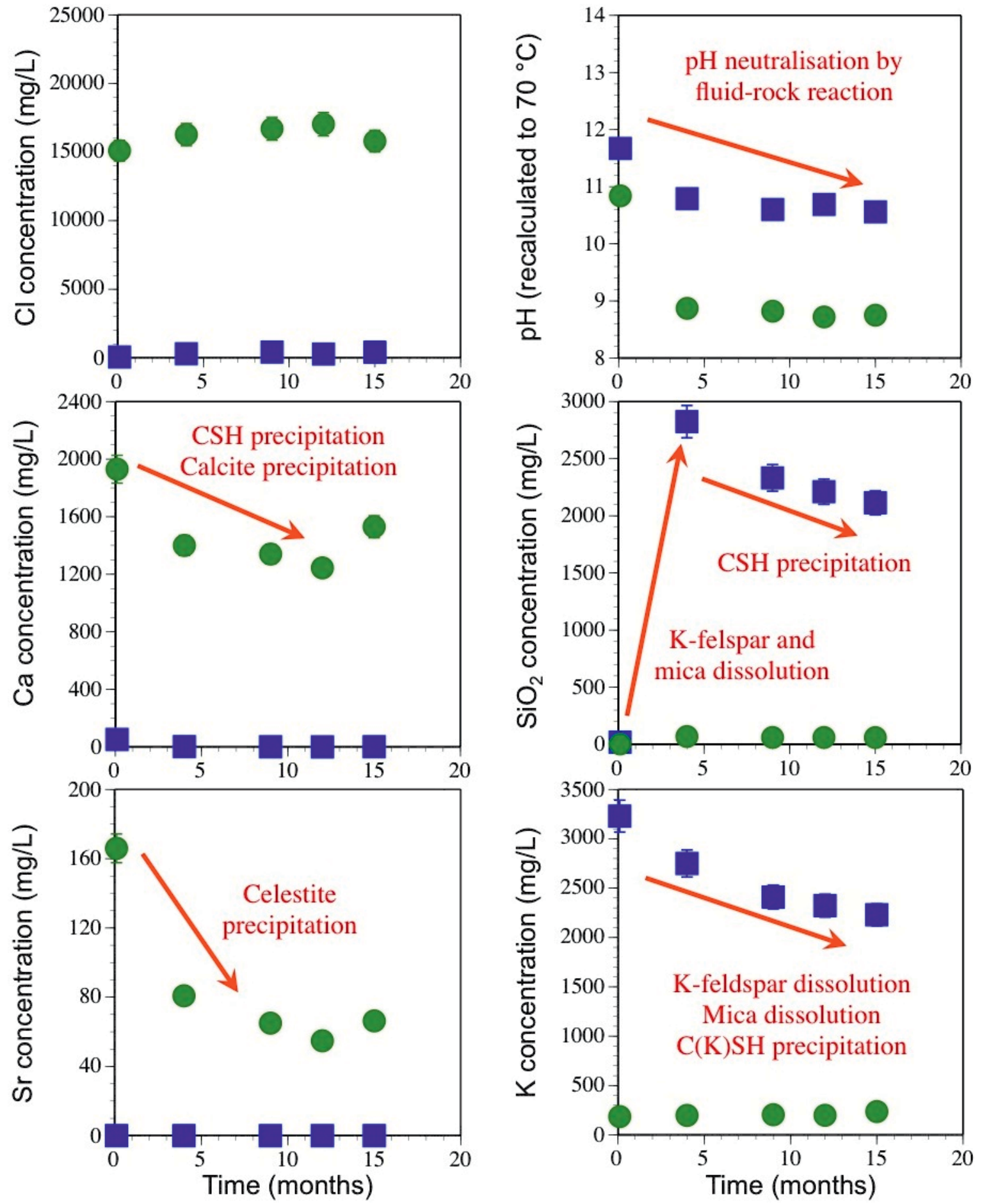


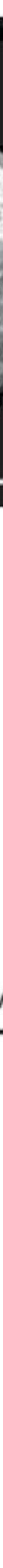




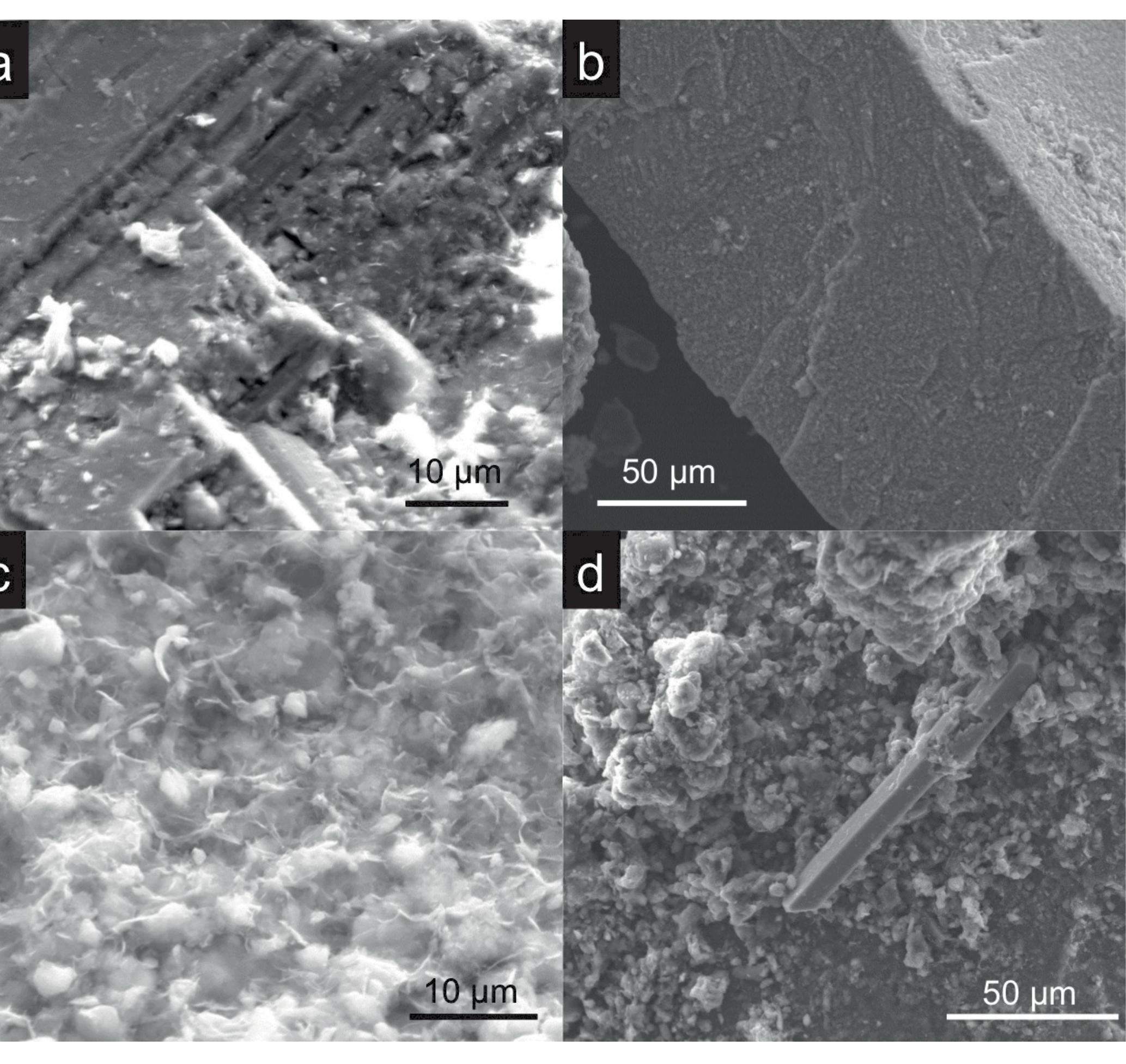




\begin{tabular}{|c|c|c|c|c|c|c|c|c|c|}
\hline \multicolumn{10}{|c|}{$\begin{array}{l}\text { Experiments to react crushed BVG with synthetic cement pore fluids } \\
\text { Temperature } 70^{\circ} \mathrm{C} \\
\text { Starting fluid = synthetic 'young near-field porewater' (YNFP) }\end{array}$} \\
\hline Time (days) & 0 & 134 & 134 & 276 & 276 & 366 & 366 & 442 & 442 \\
\hline Approximate time (mont & 0 & 4 & 4 & 9 & 9 & 12 & 12 & 15 & 15 \\
\hline Run number & - & 486 & 487 & 488 & 489 & 1521 & 1522 & 490 & 491 \\
\hline Vessel number & - & B497 & B212 & B498 & B213 & B362 & B207 & B500 & B214 \\
\hline Experimental charge & - & Crushed BVG & Blank & Crushed BVG & Blank & Crushed BVG & Blank & Crushed BVG & Blank \\
\hline Weight of BVG & - & $35.0000 \mathrm{~g}$ & & $34.9999 \mathrm{~g}$ & & $35.0002 \mathrm{~g}$ & & $35.0001 \mathrm{~g}$ & \\
\hline Initial weight of fluid & - & $140.01 \mathrm{~g}$ & $102.00 \mathrm{~g}$ & $140.02 \mathrm{~g}$ & $102.01 \mathrm{~g}$ & $139.998 \mathrm{~g}$ & $101.994 \mathrm{~g}$ & $139.98 \mathrm{~g}$ & $101.99 \mathrm{~g}$ \\
\hline Measured Eh at $70^{\circ} \mathrm{C}$ (n & $\mathrm{n} / \mathrm{a}$ & -115.5 & -56.6 & -71.5 & -2.0 & -58.2 & -77.7 & $\mathrm{n} / \mathrm{a}$ & $\mathrm{n} / \mathrm{a}$ \\
\hline Corrected Eh at $70^{\circ} \mathrm{C}$ (n & $\mathrm{n} / \mathrm{a}$ & 38.5 & 97.4 & 82.5 & 152 & 146 & 126 & $\mathrm{n} / \mathrm{a}$ & $\mathrm{n} / \mathrm{a}$ \\
\hline $\mathrm{pH}$ measured at $25^{\circ} \mathrm{C}$ & 12.96 & 12.03 & 13.12 & 11.79 & 12.93 & 11.93 & 13.03 & 11.75 & 12.94 \\
\hline $\mathrm{pH}$ recalculated to $70^{\circ} \mathrm{C}$ & 11.67 & 10.79 & 11.83 & 10.60 & 11.64 & 10.69 & 11.74 & 10.56 & 11.65 \\
\hline Ca & 51.8 & 1.84 & 24.8 & 0.840 & 12.6 & $<7.00$ & $<7.00$ & 1.27 & 7.33 \\
\hline Mg & 0.089 & $<1.00$ & $<1.00$ & $<1.00$ & $<1.00$ & $<0.50$ & $<0.50$ & $<0.20$ & $<0.20$ \\
\hline $\mathrm{Na}$ & 1890 & 1870 & 1770 & 1760 & 1810 & 2014 & 1938 & 2010 & 1890 \\
\hline $\mathbf{K}$ & 3230 & 2750 & 3450 & 2410 & 3160 & 2323 & 3005 & 2230 & 2670 \\
\hline $\mathrm{OH}$ & 2520 & 1064 & 2604 & 884 & 2680 & 823 & 2542 & 795 & 2674 \\
\hline $\mathrm{CO}_{3}$ & 166 & 2225 & 144 & 2590 & 129 & 1307 & n/a & 2769 & 226 \\
\hline $\mathrm{HCO}_{3}$ & $\mathrm{n} / \mathrm{a}$ & $\mathrm{n} / \mathrm{a}$ & $\mathrm{n} / \mathrm{d}$ & n/a & n/a & n/a & n/a & n/a & n/a \\
\hline Cl & 63.7 & 298 & 85.8 & 423 & 131 & 280 & 0.588 & 412 & 123 \\
\hline $\mathrm{SO}_{4}$ & $<1.00$ & 20.8 & 0.800 & 31.4 & 2.09 & 31.6 & 0.527 & 52.7 & $<0.50$ \\
\hline $\mathrm{NO}_{3}$ & $<1.00$ & $<1.00$ & $<0.50$ & 0.800 & 0.600 & 0.344 & 0.052 & $<1.00$ & $<0.50$ \\
\hline $\mathrm{Br}$ & $<0.50$ & $<0.50$ & $<0.25$ & $<1.50$ & $<1.50$ & 0.562 & 0.060 & 0.416 & $<0.15$ \\
\hline Total S & $\mathrm{n} / \mathrm{a}$ & 16.4 & 1.70 & 8.72 & $<2.00$ & $<17.0$ & $<17.0$ & 9.96 & $<0.40$ \\
\hline F & 19.0 & 30.0 & 24.8 & 25.8 & 25.8 & 0.432 & n/a & 23.6 & 27.3 \\
\hline $\mathrm{Si}$ & 9.20 & 1320 & 2.37 & 1090 & 2.97 & 1033 & 6.00 & 988 & 4.72 \\
\hline $\mathrm{SiO}_{2}$ & 19.7 & 2824 & 5.07 & 2332 & 6.35 & 2211 & 14.0 & 2114 & 10.1 \\
\hline Ва & $<0.010$ & $<0.010$ & $<0.012$ & $<0.010$ & $<0.010$ & $<0.004$ & $<0.004$ & $<0.002$ & 0.004 \\
\hline $\mathrm{Sr}$ & 0.018 & 0.012 & 0.032 & $<0.010$ & $<0.010$ & $<0.024$ & 0.038 & 0.014 & 0.016 \\
\hline Mn & $<0.010$ & $<0.010$ & $<0.010$ & $<0.010$ & $<0.010$ & 0.004 & $<0.002$ & $<0.002$ & $<0.002$ \\
\hline Total Fe & $<0.10$ & $<0.10$ & $<0.10$ & $<0.10$ & $<0.10$ & 0.013 & 0.019 & $<0.02$ & $<0.02$ \\
\hline Al & 12.2 & $<0.20$ & $<0.20$ & $<0.20$ & $<0.20$ & 0.017 & 0.020 & $<0.04$ & $<0.04$ \\
\hline B & $<0.20$ & $<0.50$ & $<0.50$ & 0.16 & $<0.05$ & 0.344 & $<0.144$ & 0.123 & $<0.10$ \\
\hline $\mathbf{L i}$ & $<0.10$ & $<0.05$ & $<0.05$ & $<0.005$ & $<0.005$ & 0.047 & $<0.024$ & $<0.01$ & $<0.01$ \\
\hline U & $\mathrm{n} / \mathrm{a}$ & $<0.20$ & $<0.20$ & $<0.1$ & $<0.1$ & 0.00047 & 0.00047 & $<0.1$ & $<0.1$ \\
\hline Th & n/a & $<0.20$ & $<0.20$ & $<0.4$ & $<0.4$ & 0.00013 & 0.00009 & 0.400 & 0.500 \\
\hline $\begin{array}{l}\text { Concentrations in mg/l ex } \\
\text { All solutions were filtered } \\
\text { n/a signifies that no data } \\
\text { Eh corrected for filling sol } \\
<\text { signifies concentrations }\end{array}$ & $\begin{array}{l}t \text { for } U \text { at } \\
\text { ough a } 0 \\
\text { available } \\
\text { on } 90-00 \\
\text { ow the de }\end{array}$ & $\begin{array}{l}\text { which are in } \mu g / 1 \\
\text { ilter prior to an } \\
\text { leasured } \mathrm{Eh}+2 \\
\text { limit }\end{array}$ & is - temp & Ire $\left({ }^{\circ} \mathrm{C}\right)$ & & & & & \\
\hline
\end{tabular}




\begin{tabular}{|c|c|c|c|c|c|c|c|c|c|}
\hline \multicolumn{10}{|c|}{$\begin{array}{l}\text { Experiments to react crushed BVG with synthetic cement pore fluids } \\
\text { Temperature } 70^{\circ} \mathrm{C} \\
\text { Starting fluid = synthetic 'evolved young near-field groundwater' (ENFG) }\end{array}$} \\
\hline Time (days) & 0 & 134 & 134 & 276 & 276 & 366 & 366 & 442 & 442 \\
\hline Approximate time (mont & 0 & 4 & 4 & 9 & 9 & 12 & 12 & 15 & 15 \\
\hline Run number & - & 470 & 471 & 472 & 473 & 1530 & 1529 & 474 & 475 \\
\hline Vessel number & - & B362 & B207 & В363 & B208 & B498 & B433 & B364 & B209 \\
\hline Experimental charge & - & Crushed BVG & Blank & Crushed BVG & Blank & Crushed BVG & Blank & Crushed BVG & Blank \\
\hline Weight of BVG & - & $35.0002 \mathrm{~g}$ & & $35.0000 \mathrm{~g}$ & & $34.919 \mathrm{~g}$ & & $35.0001 \mathrm{~g}$ & \\
\hline Initial weight of fluid & - & $140.02 \mathrm{~g}$ & 101.98 & $140.01 \mathrm{~g}$ & $102.02 \mathrm{~g}$ & $140.040 \mathrm{~g}$ & $102.001 \mathrm{~g}$ & $140.00 \mathrm{~g}$ & $102.02 \mathrm{~g}$ \\
\hline Measured Eh at $70^{\circ} \mathrm{C}$ (n & $\mathrm{n} / \mathrm{a}$ & 44.7 & -92.0 & -3.0 & -38.0 & -89.1 & -28.4 & -95.0 & -188.5 \\
\hline Corrected Eh at $70^{\circ} \mathrm{C}$ (n & $\mathrm{n} / \mathrm{a}$ & 199 & 62.0 & 151 & 116 & 115 & 176 & 59.0 & -34.5 \\
\hline $\mathrm{pH}$ measured at $25^{\circ} \mathrm{C}$ & 12.22 & 9.82 & 12.14 & 9.75 & 11.6 & 9.63 & 12.18 & 9.66 & 12.01 \\
\hline $\mathrm{pH}$ recalculated to $70^{\circ} \mathrm{C}$ & 10.84 & 8.87 & 10.76 & 8.82 & 10.21 & 8.72 & 10.81 & 8.75 & 10.62 \\
\hline Ca & 1930 & 1400 & 1970 & 1340 & 1950 & 1244 & 1799 & 1530 & 2090 \\
\hline Mg & 0.117 & $<1.00$ & $<1.00$ & $<0.10$ & $<0.10$ & $<0.50$ & $<0.50$ & $<0.20$ & $<0.20$ \\
\hline $\mathrm{Na}$ & 9160 & 9550 & 9110 & 8630 & 8850 & 9954 & 9624 & 9110 & 9300 \\
\hline $\mathbf{K}$ & 185 & 197 & 156 & 204 & 176 & 198 & 169 & 236 & 214 \\
\hline $\mathrm{OH}$ & 459 & 11.0 & 493 & n/a & 451 & $<20.0$ & 444 & $\mathrm{n} / \mathrm{a}$ & 473 \\
\hline $\mathrm{CO}_{3}$ & $<20.0$ & 9.00 & n/a & n/a & 39 & $\mathrm{n} / \mathrm{a}$ & 39.0 & n/a & 40 \\
\hline $\mathrm{HCO}_{3}$ & $\mathrm{n} / \mathrm{a}$ & $\mathrm{n} / \mathrm{a}$ & n/a & 47 & n/a & $\mathrm{n} / \mathrm{a}$ & n/a & 50 & n/a \\
\hline $\mathrm{Cl}$ & 15100 & 16270 & 15100 & 16700 & 16400 & 17030 & 16305 & 15796 & 15659 \\
\hline $\mathrm{SO}_{4}$ & 1090 & 1060 & 1090 & 1060 & 1160 & 1038 & 1123 & 1084 & 1182 \\
\hline $\mathrm{NO}_{3}$ & $<20.00$ & $<20.0$ & $<20.0$ & $<10.0$ & $<10.0$ & $<12.0$ & $<12.0$ & $<5.00$ & $<5.00$ \\
\hline $\mathrm{Br}$ & 23.2 & 25.6 & 25.2 & 24.8 & 22.7 & 14.6 & 15.6 & 27.5 & 27.3 \\
\hline Total S & n/a & 364 & 378 & 326 & 369 & 373 & 410 & 330 & 382 \\
\hline F & 0.03 & 0.45 & 0.07 & 0.480 & 0.060 & $<2.0$ & $<2.0$ & 0.550 & 0.080 \\
\hline $\mathrm{Si}$ & 2.07 & 32.4 & $<0.20$ & 28.5 & 0.090 & 28.4 & 0.300 & 28.1 & 0.050 \\
\hline $\mathrm{SiO}_{2}$ & 4.43 & 69.3 & $<0.43$ & 61.0 & 0.193 & 60.8 & 0.700 & 60.0 & 0.107 \\
\hline Ва & 0.017 & $<0.010$ & 0.022 & 0.005 & 0.013 & 0.014 & 0.297 & 0.006 & 0.017 \\
\hline $\mathrm{Sr}$ & 166 & 80.8 & 174 & 65.0 & 180 & 54.8 & 143 & 66.3 & 184 \\
\hline Mn & $<0.010$ & $<0.010$ & $<0.010$ & $<0.001$ & $<0.001$ & $<0.002$ & $<0.002$ & $<0.002$ & $<0.002$ \\
\hline Total Fe & 0.120 & $<0.10$ & $<0.10$ & $<0.01$ & $<0.01$ & $<0.013$ & $<0.013$ & $<0.02$ & $<0.02$ \\
\hline Al & 4.17 & $<0.50$ & $<0.50$ & 0.259 & 0.316 & 0.008 & 0.107 & 0.396 & 0.430 \\
\hline B & 0.335 & $<0.50$ & $<0.50$ & 0.097 & $<0.05$ & $<0.144$ & $<0.144$ & 0.110 & $<0.10$ \\
\hline $\mathbf{L i}$ & 0.153 & 3.93 & $<0.10$ & 3.01 & 0.150 & 2.66 & $<0.024$ & 2.84 & 0.154 \\
\hline U & n/a & $<0.20$ & $<0.20$ & $<0.1$ & $<0.1$ & $<0.00007$ & $<0.00007$ & $<0.1$ & $<0.1$ \\
\hline Th & n/a & $<0.20$ & $<0.20$ & $<0.4$ & $<0.4$ & $<0.00009$ & $<0.00009$ & $<0.2$ & $<0.2$ \\
\hline $\begin{array}{l}\text { Concentrations in mg/l ex } \\
\text { All solutions were filtered } \\
\text { n/a signifies that no data } \\
\text { Eh corrected for filling sol } \\
\text { < signifies concentrations }\end{array}$ & $\begin{array}{l}t \text { for } U \text { ar } \\
\text { ough a } 0 \text {. } \\
\text { available } \\
\text { on 90-00- } \\
\text { ow the de }\end{array}$ & $\begin{array}{l}\text { which are in } \mu g / / \\
\text { ilter prior to an } \\
\text { leasured } E h+2 \\
\text { limit }\end{array}$ & is & & & & & & \\
\hline
\end{tabular}




\begin{tabular}{|c|c|c|c|c|c|c|c|c|c|}
\hline \multicolumn{10}{|c|}{$\begin{array}{l}\text { Experiments to react crushed BVG with synthetic cement pore fluids } \\
\text { Temperature } 70^{\circ} \mathrm{C} \\
\text { Starting fluid = synthetic 'young near-field porewater' (YNFP) }\end{array}$} \\
\hline Time (days) & 0 & 134 & 134 & 276 & 276 & 366 & 366 & 442 & 442 \\
\hline Run number & - & 486 & 487 & 488 & 489 & 1521 & 1522 & 490 & 491 \\
\hline Experimental charge & - & Crushed BVG & Blank & Crushed BVG & Blank & Crushed BVG & Blank & Crushed BVG & Blank \\
\hline Acmite & & & & & & 4.59 & -2.18 & & \\
\hline Afwillite & 2.34 & -1.46 & 0.32 & -3.61 & -0.49 & & & -3.26 & -0.82 \\
\hline Albite-high & -6.98 & & & & & -0.24 & -10.61 & & \\
\hline Albite-low & -5.87 & & & & & 0.86 & -9.50 & & \\
\hline Analcime & -3.18 & & & & & 0.40 & -6.50 & & \\
\hline Aragonite & 0.91 & 0.51 & 0.44 & 0.20 & 0.24 & & & 0.38 & 0.22 \\
\hline $\mathrm{C}_{2} \mathrm{SH}$ (alpha) & 1.51 & -2.09 & 0.45 & -3.56 & -0.23 & & & -3.33 & -0.51 \\
\hline $\mathrm{CaCO}_{3} \cdot \mathrm{H}_{2} \mathrm{O}_{(\mathrm{s})}$ & 0.09 & -0.31 & -0.38 & -0.62 & -0.58 & & & -0.44 & -0.60 \\
\hline Calcite & 1.09 & 0.68 & 0.61 & 0.38 & 0.42 & & & 0.55 & 0.39 \\
\hline Clinoptilolite_K & -13.07 & & & & & -0.62 & -17.59 & & \\
\hline Cristobalite & -3.56 & -0.36 & -4.40 & -0.24 & -4.01 & -0.35 & -3.85 & -0.25 & -3.82 \\
\hline $\mathrm{CSH}_{0.8}$ & -0.77 & -0.28 & -1.69 & -0.80 & -1.73 & & & -0.71 & -1.73 \\
\hline Ferryhydrite & & & & & & -0.11 & -1.00 & & \\
\hline Fluorite & -0.03 & -1.29 & -0.25 & -1.82 & -0.35 & & & -1.71 & -0.56 \\
\hline Goethite & & & & & & 2.11 & 1.22 & & \\
\hline Gyrolite & 0.29 & 3.09 & -2.45 & 1.87 & -2.34 & & & 2.09 & -2.25 \\
\hline Hematite & & & & & & 6.03 & 4.26 & & \\
\hline Heulandite_Na & -13.09 & & & & & 2.73 & -20.99 & & \\
\hline Hillebrandite & 0.58 & -3.02 & -0.48 & -4.49 & -1.15 & & & -4.25 & -1.44 \\
\hline HNontronite-K & & & & & & 0.01 & -14.54 & & \\
\hline HNontronite-Na & & & & & & 0.53 & -14.04 & & \\
\hline Illite-Fe $^{\text {II }}$ & & & & & & -0.39 & -13.97 & & \\
\hline Jaffeite & 4.41 & -9.59 & 2.05 & -14.14 & -0.35 & & & -13.41 & -1.39 \\
\hline Jennite & 6.65 & -4.74 & 0.60 & -11.19 & -1.83 & & & -10.12 & -2.82 \\
\hline Lepidocrocite & & & & & & 1.81 & 0.92 & & \\
\hline Maghemite(disord) & & & & & & 2.29 & 0.52 & & \\
\hline Maghemite(ord) & & & & & & 2.08 & 0.31 & & \\
\hline Magnetite & & & & & & 0.60 & -2.56 & & \\
\hline Microcline & -3.78 & & & & & 2.87 & -7.46 & & \\
\hline Nontronite-K & & & & & & -0.16 & -14.72 & & \\
\hline Nontronite-Na & & & & & & -0.61 & -15.17 & & \\
\hline Okenite & -1.43 & 1.57 & -3.22 & 1.02 & -2.97 & & & 1.13 & -2.83 \\
\hline Phillipsite_K & -4.00 & & & & & 2.65 & -7.69 & & \\
\hline Phillipsite_Na & -5.00 & & & & & 1.74 & -8.63 & & \\
\hline Portlandite & -0.40 & -3.80 & -0.51 & -4.60 & -1.05 & & & -4.48 & -1.28 \\
\hline Quartz & -3.09 & 0.11 & -3.93 & 0.24 & -3.54 & 0.12 & -3.38 & 0.23 & -3.35 \\
\hline Sanidine & -4.11 & & & & & 2.54 & -7.80 & & \\
\hline $\mathrm{SiO}_{2(\mathrm{am})}$ & -3.95 & -0.74 & -4.78 & -0.62 & -4.39 & -0.74 & -4.23 & -0.63 & -4.20 \\
\hline $\mathrm{SrSiO}_{3(\mathrm{~s})}$ & -1.83 & -0.76 & -2.18 & & & & -1.66 & -1.09 & -2.17 \\
\hline Strontianite & -1.95 & -1.09 & -1.83 & & & & & -0.99 & -1.84 \\
\hline Tobermorite-11A & 2.01 & 4.22 & -3.58 & 0.97 & -3.89 & & & 1.54 & -3.94 \\
\hline Tobermorite-14A & 3.14 & 5.35 & -2.45 & 2.11 & -2.76 & & & 2.68 & -2.81 \\
\hline Trona & -12.33 & -9.43 & -12.67 & -9.20 & -12.51 & -9.59 & & -9.00 & -12.01 \\
\hline Truscottite & -6.26 & 8.35 & -17.10 & 4.25 & -16.13 & & & 5.02 & -15.52 \\
\hline Vaterite & 0.61 & 0.20 & 0.13 & -0.10 & -0.07 & & & 0.07 & -0.09 \\
\hline Xonotlite & 0.31 & -0.89 & -5.40 & -4.94 & -6.24 & & & -4.24 & -6.53 \\
\hline
\end{tabular}




\begin{tabular}{|c|c|c|c|c|c|c|c|c|c|}
\hline \multicolumn{10}{|c|}{$\begin{array}{l}\text { Experiments to react crushed BVG with synthetic cement pore fluids } \\
\text { Temperature } 70^{\circ} \mathrm{C} \\
\text { Starting fluid = synthetic 'young near-field porewater' (YNFP) }\end{array}$} \\
\hline Time (days) & 0 & 134 & 134 & 276 & 276 & 366 & 366 & 442 & 442 \\
\hline Run number & - & 470 & 471 & 472 & 473 & 1530 & 1529 & 474 & 475 \\
\hline Experimental charge & - & Crushed BVG & Blank & Crushed BVG & Blank & Crushed BVG & Blank & Crushed BVG & Blank \\
\hline Afwillite & 3.21 & -3.08 & & -3.45 & -1.89 & -4.15 & 1.18 & -3.68 & -0.79 \\
\hline Albite-high & -6.16 & & & 1.23 & -9.42 & -0.11 & -10.15 & 1.50 & -11.30 \\
\hline Albite-low & -5.05 & & & 2.34 & -8.32 & 1.00 & -9.05 & 2.61 & -10.20 \\
\hline Analcime & -2.60 & & & 1.96 & -5.15 & 0.59 & -5.78 & 2.20 & -6.36 \\
\hline Anhydrite & & -0.2123 & -0.1309 & -0.259 & -0.1128 & -0.2654 & -0.1589 & -0.2155 & -0.104 \\
\hline Anorthite & -3.02 & & & 0.22 & -6.64 & -2.80 & -7.89 & 0.68 & -7.74 \\
\hline Aragonite & & 0.4863 & & 1.2018 & 1.3254 & & 1.23 & 1.2378 & 1.3218 \\
\hline Barite & & & -1.138 & -1.7842 & -1.3732 & -1.3024 & 0.0172 & -1.7165 & -1.2582 \\
\hline Bassanite & & -0.7489 & -0.6675 & -0.7956 & -0.6494 & -0.8023 & -0.6957 & -0.752 & -0.6406 \\
\hline Beidellite-Ca & -10.29 & & & 1.43 & -14.24 & -1.80 & -16.93 & 2.09 & -17.24 \\
\hline Beidellite-K & -9.08 & & & 2.67 & -13.04 & -0.55 & -15.72 & 3.34 & -16.01 \\
\hline Beidellite-Na & -8.90 & & & 2.82 & -12.87 & -0.37 & -15.52 & 3.48 & -15.86 \\
\hline Boehmite & -1.14 & & & -0.33 & -1.64 & -1.75 & -2.71 & -0.08 & -1.92 \\
\hline $\mathrm{CaCO}_{3} \cdot \mathrm{H}_{2} \mathrm{O}_{(\mathrm{s})}$ & & -0.3379 & & 0.3778 & 0.5013 & & 0.4055 & 0.4138 & 0.4976 \\
\hline Calcite & & 0.6601 & & 1.3756 & 1.4992 & & 1.4037 & 1.4115 & 1.4955 \\
\hline Celestite & & -0.0956 & 0.2209 & -0.2213 & 0.2201 & -0.2571 & 0.1578 & -0.2201 & 0.2325 \\
\hline $\mathrm{C}_{2} \mathrm{SH}$ (alpha) & 2.02 & -3.14 & & -3.38 & -1.15 & -3.86 & 0.94 & -3.54 & -0.18 \\
\hline Chabazite & -3.91 & & & 5.07 & -8.96 & 2.13 & -10.40 & 5.58 & -11.41 \\
\hline Clinoptilolite_Ca & -11.04 & & & 1.66 & -15.73 & 0.15 & -16.79 & 2.00 & -18.90 \\
\hline Clinoptilolite_K & -13.95 & & & -1.15 & -18.69 & -2.65 & -19.71 & -0.77 & -21.77 \\
\hline Clinoptilolite_Na & -12.91 & & & -0.18 & -17.64 & -1.60 & -18.60 & 0.15 & -20.79 \\
\hline Cristobalite & -3.33 & -0.43 & & -0.46 & -4.04 & -0.42 & -4.14 & -0.44 & -4.72 \\
\hline $\mathrm{CSH}_{0.8}$ & -0.43 & -0.75 & & -0.86 & -2.12 & -1.03 & -1.34 & -0.91 & -2.14 \\
\hline $\mathrm{CSH}_{1.2}$ & 0.08 & -1.85 & & -2.01 & -2.10 & -2.28 & -0.89 & -2.09 & -1.79 \\
\hline $\mathrm{CSH}_{1.6}$ & 0.23 & -3.31 & & -3.51 & -2.44 & -3.89 & -0.79 & -3.64 & -1.80 \\
\hline Diaspore & -0.50 & & & 0.32 & -0.99 & -1.11 & -2.06 & 0.57 & -1.27 \\
\hline Ettringite & & & & -8.1436 & -1.59 & -11.7966 & -0.6131 & -7.7768 & 0.3389 \\
\hline Foshagite & 2.68 & -4.73 & & -5.25 & -4.36 & -6.16 & -0.29 & -5.55 & -3.11 \\
\hline Gibbsite & -1.52 & & & -0.71 & -2.01 & -2.13 & -3.09 & -0.45 & -2.29 \\
\hline Gismondine & 2.04 & & & 8.51 & -5.22 & 2.46 & -7.72 & 9.43 & -7.41 \\
\hline Gypsum & & -0.4435 & -0.3617 & -0.4898 & -0.3438 & -0.4973 & -0.3907 & -0.4462 & -0.3351 \\
\hline Gyrolite & 1.25 & 1.91 & & 1.60 & -3.33 & 1.20 & -1.44 & 1.48 & -3.72 \\
\hline HBeidellite-Ca & -8.45 & & & 3.26 & -12.41 & 0.03 & -15.09 & 3.92 & -15.40 \\
\hline HBeidellite-K & -8.91 & & & 2.84 & -12.88 & -0.39 & -15.55 & 3.51 & -15.85 \\
\hline HBeidellite-Na & -7.78 & & & 3.94 & -11.75 & 0.74 & -14.40 & 4.60 & -14.74 \\
\hline Heulandite_Ca & -11.66 & & & 5.37 & -18.89 & 2.32 & -20.69 & 5.97 & -23.26 \\
\hline Heulandite_Na & -11.26 & & & 5.82 & -18.57 & 2.96 & -20.17 & 6.40 & -22.89 \\
\hline Hillebrandite & 1.09 & -4.07 & & -4.31 & -2.08 & -4.79 & 0.01 & -4.47 & -1.11 \\
\hline Illite-Al & -5.50 & & & 4.19 & -9.69 & 0.17 & -12.56 & 4.98 & -12.20 \\
\hline Jaffeite & 5.70 & -12.68 & & -13.37 & -3.09 & -14.84 & 3.26 & -13.88 & 0.49 \\
\hline Jennite & 9.25 & -9.60 & & -10.73 & -6.05 & -12.82 & 3.18 & -11.42 & -2.72 \\
\hline Kaolinite & -7.11 & & & 0.26 & -9.51 & -2.51 & -11.86 & 0.81 & -11.43 \\
\hline Laumontite & -3.97 & & & 5.01 & -9.02 & 2.07 & -10.46 & 5.52 & -11.47 \\
\hline Margarite & -2.29 & & & 2.57 & -6.90 & -3.29 & -10.30 & 3.54 & -8.55 \\
\hline Merlinoite_Na & -4.96 & & & -0.60 & -7.53 & -2.05 & -8.18 & -0.35 & -8.70 \\
\hline Microcline & -4.90 & & & 2.56 & -8.18 & 1.14 & -8.96 & 2.86 & -9.99 \\
\hline Mordenite_Ca & -11.70 & & & 1.29 & -16.36 & -0.12 & -17.39 & 1.61 & -19.60 \\
\hline Mordenite_Oregon & -12.84 & & & 0.53 & -17.48 & -0.70 & -18.44 & 0.83 & -20.78 \\
\hline Muscovite & -5.12 & & & 3.97 & -9.37 & -0.30 & -12.30 & 4.79 & -11.75 \\
\hline Natrolite & -4.32 & & & 1.84 & -8.73 & -0.97 & -9.89 & 2.31 & -10.45 \\
\hline Okenite & -0.84 & 0.94 & & 0.78 & -3.48 & 0.60 & -2.59 & 0.73 & -4.02 \\
\hline Paragonite & -6.35 & & & 2.66 & -10.60 & -1.53 & -13.48 & 3.44 & -13.04 \\
\hline Phillipsite_Ca & -5.11 & & & 2.26 & -8.34 & 0.83 & -9.16 & 2.53 & -10.24 \\
\hline Phillipsite_K & -5.14 & & & 2.32 & -8.42 & 0.90 & -9.20 & 2.63 & -10.23 \\
\hline Phillipsite_Na & -4.19 & & & 3.20 & -7.46 & 1.85 & -8.19 & 3.47 & -9.34 \\
\hline Portlandite & -0.27 & -4.30 & -0.43 & -4.40 & -1.49 & -4.66 & -0.40 & -4.49 & -0.67 \\
\hline Pyrophyllite & -13.12 & & & 0.00 & -16.94 & -2.69 & -19.48 & 0.59 & -20.21 \\
\hline Quartz & -2.86 & 0.05 & & 0.02 & -3.57 & 0.05 & -3.67 & 0.04 & -4.25 \\
\hline Sanidine & -5.24 & & & 2.22 & -8.51 & 0.80 & -9.29 & 2.53 & -10.32 \\
\hline Scolecite & -2.19 & & & 3.92 & -6.53 & 0.94 & -7.88 & 4.40 & -8.30 \\
\hline $\mathrm{SiO}_{2(\mathrm{am})}$ & -3.71 & -0.81 & & -0.84 & -4.42 & -0.80 & -4.52 & -0.82 & -5.10 \\
\hline $\mathrm{SrF}_{2(\mathrm{cr})}$ & -7.18 & -5.13 & -6.45 & -5.15 & -6.57 & 0.09 & 0.54 & -5.04 & -6.32 \\
\hline $\mathrm{SrSiO}_{3(\mathrm{~s})}$ & 0.66 & -0.70 & & -0.92 & -1.29 & -1.16 & -0.32 & -1.03 & -1.15 \\
\hline Stellerite & -30.59 & & & 4.63 & -44.94 & -1.04 & -48.42 & 5.76 & -53.90 \\
\hline Stilbite & -23.92 & & & 7.19 & -38.70 & 0.03 & -42.52 & 8.51 & -46.83 \\
\hline Strontianite & & -0.4929 & & 0.1436 & 0.5624 & & 0.4507 & 0.1372 & 0.5623 \\
\hline Tobermorite-11A & 4.08 & 1.35 & & 0.64 & -6.31 & -0.42 & -1.45 & 0.31 & -6.27 \\
\hline Tobermorite-14A & 5.19 & 2.47 & & 1.75 & -5.20 & 0.69 & -0.34 & 1.43 & -5.16 \\
\hline Truscottite & -2.51 & 4.14 & & 3.03 & -19.61 & 1.69 & -13.14 & 2.65 & -21.99 \\
\hline Vaterite & & 0.1791 & & 0.8946 & 1.0182 & & 0.9228 & 0.9306 & 1.0145 \\
\hline Wairakite & -5.95 & & & 3.04 & -10.99 & 0.09 & -12.44 & 3.54 & -13.44 \\
\hline Zeolite_CaP & -2.94 & & & 3.54 & -10.19 & -2.51 & -12.70 & 4.46 & -12.38 \\
\hline
\end{tabular}

